\title{
Results of Researches of some Rare Species of Raptors in the Nechkinsky National Park, Russia
}

\section{РЕЗУЛЬТАТЫ ИССЛЕДОВАНИЙ НЕКОТОРЫХ РЕДКИХ ВИДОВ ПЕРНАТЫХ ХИЩНИКОВ В НАЦИОНАЛЬНОМ ПАРКЕ «НЕЧКИНСКИЙ», РОССИЯ}

\author{
Bekmansurov R.H. (Kazan Federal University, Elabuga Institute; National Park \\ "Nizhnyaya Kama", Elabuga, Republic of Tatarstan, Russia) \\ Бекмансуров Р.X. (Казанский федеральный университет, Елабужский институт; \\ ФГБУ Национальный парк «Нижняя Кама», Елабуга, Республика Татарстан, Россия)
}

\section{Контакт:}

Ринур Бекмансуров

Казанский

федеральный

университет

Елабужский институт

Национальный парк

«нижняя Кама»

Россия 423607

Республика Татарстан

Елабуга

ул. Казанская, 89

тел.: +7855 5775455

rinur@yandex.ru

Contact:

Rinur Bekmansurov

Kazan Federal University

Elabuga Institute;

National Park

"Nizhnyaya Kama"

Kazaknskaya str., 89

Elabuga

Republic of Tatarstan

Russia 423600

tel.: +78555775455

rinur@yandex.ru
Резюме

В Аанном сообшении представлены результаты изучения отдельных редких видов хишных птиц в национальном парке «Нечкинский» (УАмуртсткая Республика, Россия) в 2016, 2017, 2019 и 2021 гг., спустя 20 лет после первых исследований, проведённых здесь И.В. Карякиным в 1991-1996 годах. Основные усилия были направлены на

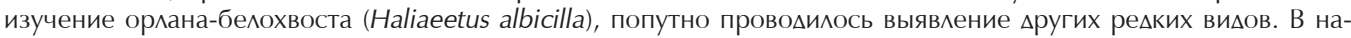
циональном парке (НП) в пределах ранее известных гнездовых территорий орланов выявлены 3 новых гнезда, которые смешены на 0,9-1,6 км от мест расположения старых гнёзs, най еенных 20 ^ет назад. Несмотря на неполное обследование территории, предполагается наличие в национальном парке 8-9 гнездовых территорий и 2-3 территорий непосредственно вАоль его границ. Численность гнездяшихся пар орланов в сравнении с первой половиной 1990-х гг. остаётся стабильной, а увеличения численности, как это произошло на Нижней Каме в Татарстане, здесь не отмечено. Орланы гнездятся на крупных, старовозрастных соснах и лиственницах, с удалением вглубь леса от внешней опушки на расстояние 130-530 м. Аистанция Ао р. Камы в среднем состав-

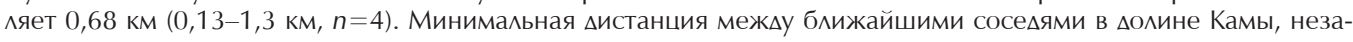
регулированной водохранилишем, в настояшее время составляет 3,6 км, средняя $(n=3)-3,9$ км. Размножение орланов происходит нерегулярно, с перерывами. Отмечено отсутствие размножения по 2-3 года. Период от-

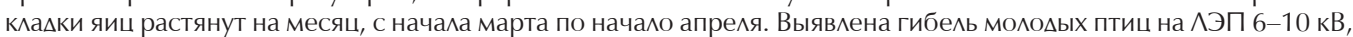
в результате влацельцев обязали оборудовать АЭП птицезашитными устройствами. Проводилось кольцевание птенцов орланов-белохвостов цветными кольцами и получены два повторных наблюдения с низовий Камы. В нацпарке продолжает обитать большой подорлик (Aquila clanga), что полтверждено встречами взрослых птиц. Произошёл рост численности сапсана (Falco peregrinus) в сравнении с первой половиной 1990-х гг. в $\Delta$ ва-три раза. Выявлено гнездование этого сокола на 2-х участках с мистанцией между ними 16,5 км.

Ключевые слова: пернатые хишники, орлан-белохвост, Haliaeetus albicilla, большой подорлик, Aquila clanga, сапсан, Falco peregrinus, гнездовая территория, гнездовой участок, гнезАо, кольцевание, УАмуртия.

Поступияа в рехакцию: 12.12.2021 г. Принята к публикации: 19.12.2021 г.

Abstract

This report presents the selected results of rare birds of prey studies in the Nechkinsky National Park (Udmurt Republic, Russia) 20 years after the first studies undertaken here by I.V. Karyakin in 1991-1996. The main efforts were directed to the study of the White-Tailed Eagle (Haliaeetus albicilla). At the same time, the identification of other rare species was made. The studies were carried out during short visits to the territory in 2016, 2017, 2019, and 2021. In the national park (NP), within the previously known breeding areas, 3 new nests were identified. They were 0.9-1.6 km displaced from the locations of the old nests found 20 years ago. A new breeding territory was found in the adjacent area near the border of the NP. Despite the incomplete study of the area, it is assumed to be 8-9 breeding areas in the national park, and 2-3 areas directly along its borders. The number of breeding pairs of eagles in comparison with the first half of the 1990s, according to the author, remains stable, and population increase, as happened on the Lower Kama in Tatarstan, has not been observed here. Eagles nest on large, old-growth pines and larch trees, with a distance of 130-530 m deep into the forest from the outer edge. The distance to the Kama River is $0.68 \mathrm{~km}$ on average $(0.13-1.3 \mathrm{~km}, n=4)$. The minimum distance between the nearest neighbors in the Kama valley, unregulated by the reservoir, is currently $3.6 \mathrm{~km}$, the average $(n=3)-3.9 \mathrm{~km}$. Eagles breed occasionally on and off. No reproduction was recorded for $2-3$ years. The period of egg laying extends for a month from the beginning of March to the beginning of April. The death of young birds on 6-10 kV power lines was revealed, as a result, the owners were obliged to equip the power lines with bird protection devices. White-Tailed Eagle nestlings were ringed with colored rings. Two repeated observations were obtained from the lower reaches of Kama. The Greater Spotted Eagle (Aquila clanga) continues to inhabit the National Park, which is confirmed by the meetings of adult birds. There has been two-three times population of the Peregrine Falcon (Falco peregrinus) in comparison with the first half of the 1990s. Breeding of this falcon was found on 2 territories with a distance of $16.5 \mathrm{~km}$ between them.

Keywords: birds of prey, White-Tailed Eagle, Haliaeetus albicilla, Greater Spotted Eagle, Aquila clanga, Peregrine Falcon, Falco peregrinus, breeding site, breeding territory, nest, ringing, Udmurtia.

Received: 12/12/2021. Accepted: 19/12/2021.

DOI: $10.19074 / 1814-8654-2021-43-214-236$ 


\section{Введение}

Находяшийся в УАмуртской Республике национальный парк «Нечкинский» (Аалее НП) образован в 1997 г. В период с 1991 по 1996 гг. на территории, которая в последуюшем была включена в состав национального парка, а также на прилегаюшей к ней сопредельной территории, исследованиями И.В. Карякина (1998) было выявлено гнезАование ряда редких видов хишных птиц: непосредственно в границах НП гнездимись: скопа (Pandion haliaetus), орлан-белохвост (Haliaeetus albicilla), большой подорлик (Aquila Clanga), сапсан (Falco peregrinus), а на сопрелельной территории выявлено также гнездование беркута (Aquila chrysaetos). $\Delta а н-$ ные виды включены в Красные книги Российской Федерации и УАмуртской Республики (Приказ..., 2020; Красная книга..., 2012).

Спустя 20 мет статус и численность этих редких виАов могли измениться, что требова^о проведения мониторинга их гнезАовых группировок. Орлан-белохвост стал к^ючевым видом в рамках программы Российской сети изучения и охраны пернатых хишников, поэтому на его изучение были направлены основные усилия. В 2016 г. на сопредельной территории у границы НП бы^о осмотрено ранее неизвестное гнезАо и в нём окольцованы птенцы. Предполага^ось, что численность орлана-белохвоста увеличилась, как это произошло, например, в соседнем Татарстане (Бекмансуров, Аюпов, 2016). В последуюшем было предпринято обследование территории НП с целью поиска гнёзд орлана-белохвоста $А \wedge я$ подтвержления роста его численности, а

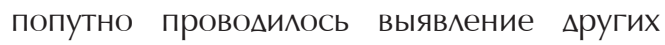
реАких виАов.

В Аанном сообшении представлены отмельные результаты этих исследований, проведённых в ходе коротких посешений территории в 2016, 2017, 2019 и 2021 гг.

Обшая характеристика мандшафтно-экомогических условий территории нашионального парка «Нечкинский»

НП «Нечкинский» расположен на юговостоке УАмуртской Республики у границы с Пермским краем, вАоль среднего течения реки Камы в районе нижнего бьефра Воткинского водохранилиша. Его обшая плошаАь - 20752 га. Парк также характеризуется расположением на стыке трёх природно-климатических зон: тайги, широколиственных лесов и лесостепи. ^есные экосистемы занимают большую часть территории НП, которая Аелится на 2 участковых лесничества: Костоватовское

\section{Introduction}

The Nechkinsky National Park (NP) located in the Udmurt Republic was formed in 1997. From 1991 to 1996, in the territory that was later included in the national park, as well as in the adjacent area, the studies of I.V. Karyakin (1998) revealed the breeding of a number of rare species of birds of prey: the Osprey (Pandion haliaetus), the White-Tailed Eagle (Haliaeetus albicilla), the Greater Spotted Eagle (Aquila Clanga), the Peregrine Falcon (Falco peregrinus) nested directly within the borders of the NP, and in the adjacent area breeding of the Golden Eagle (Aquila chrysaetos) was also revealed.

Twenty years later, the status and abundance of these rare species could have changed, which required monitoring of their breeding groups. The White-Tailed Eagle became a key species within the program of the Russian Raptor Research and Conservation Network, that is why the main efforts were directed to its study. In 2016, a previously unrecorded nest was examined in the adjacent area near the border of the NP, and nestlings were ringed in it. It was assumed that the White-Tailed Eagle population number increased, as happened, for example, in neighboring Tatarstan (Bekmansurov, Ayupov, 2016). Subsequently, a study of the NP territory was made to search for White-Tailed Eag-le nests to confirm the growth of its number, and at the same time, other rare species were identified.

This report presents selected results of these studies carried out during short visits to the territory in 2016, 2017, 2019, and 2021.

General characteristics of landscape and environmental conditions of the territory of the National Park "Nechkinsky"

NP "Nechkinsky" is located in the southeast of the Udmurt Republic near the border with the Perm Territory along the middle reach of the Kama River in the area of the lower pond of the Votkinsk Reservoir. Its total area is 20,752 hectares. The park is also characterized by its location at the junction of three natural and climatic zones: taiga, deciduous forests, and forest-steppe. Forest ecosystems occupy most of the NP territory, which is divided into 2 district forestries: Kostovatovsky and Nechkinsky. Both forestries directly border on forest husbandries not being a part of the National Park.

In general, the presence of forest areas in the NP with high old-growth coniferous trees, pine and larch, along the coastal zone in both forestries creates favorable conditions for breeding of such a semi-aquatic bird of prey 


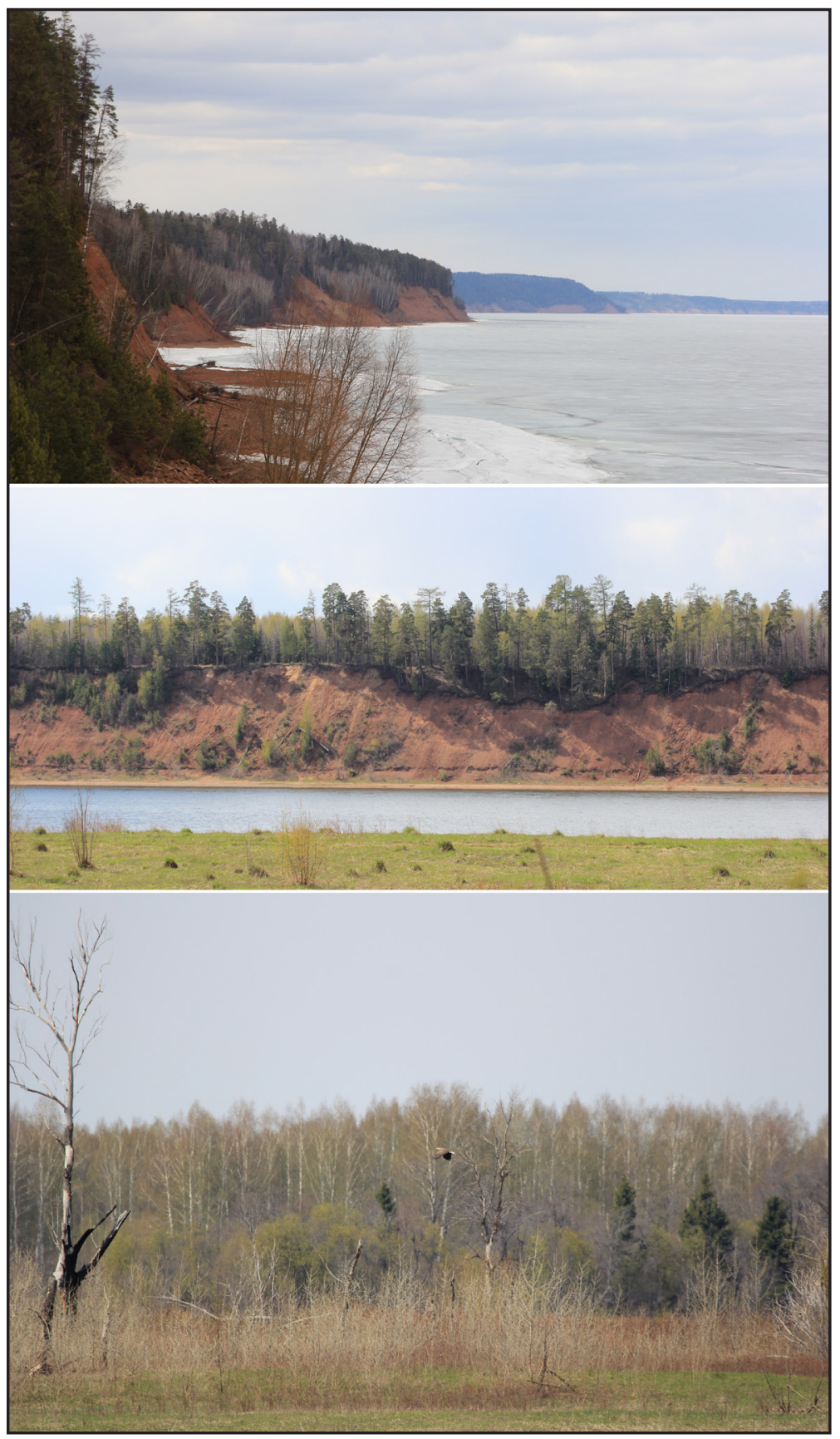

и Нечкинское. Оба лесничества непосредственно граничат с лесными хозяйствами, не относяшимися к национальному парку.

Костоватовское лесничество расположено в правобережье р. Камы, в межлуречье с её притоком рекой Сивой. Аесничество занимает большую часть одноимённого бора, разделяя его с Волковским участком Воткинского месничества. Северо-восточная часть Костоватовского месничества наиболее высокая в рельефре, занимает водоразмельные склоны с высокими обрывистыми берегами вАоль Воткинского водохранилиша, сложенными отложениями пермского периода. В этой части месничества сохраняются участки таёжных лесов с елями, пихтами и крупными миственницами. 3Аесь так-
Вид на участок Костоватовского лесничества по западному побережью Воткинского водохранимиша (вверху), виА на левобережный скАон р. Камы и Чайковское лесничество ниже Воткинской ГЭС (в центре) и участок Камской поймы ниже Воткинской ГЭС (внизу). Фото Р. Бекмансурова.

View of the site of the Kostovatovsky Forestry along the western coast of the Votkinsk Reservoir (above), view of the left-bank slope of the Kama river of the Chaikovskoe Forestry below the Votkinsk Hydroelectric Dam (at the center) and the section of the Kama floodplain below the Votkinskaya Hydroelectric Dam (below).

Photos by R. Bekmansurov.

as the White-Tailed Eagle. The presence of black alder forests in the wetlands of the terrace near flood plain makes it possible for the Greater Spotted Eagle breeding.

\section{Terms used}

Breeding territory - the territory around the nest protected by a pair of territorial birds (Karyakin, 2004; Romanov, Masterov, 2014; Viter, 2015).

Breeding area - an area covering the zone of all nests (breeding territories), hunting territories used by a pair of birds for several years and where contact with territorial birds is possible. This is, in fact, the same as the "long-term breeding territory" (Galushin, 1971). One constant pair corresponds to one breeding area.

For more than 20 years within the same breeding area in NP "Nechkinsky", individuals could change repeatedly, and nests and breeding territories could also change.

\section{Materials and methods}

The search for nests was carried out mainly in 2017 and 2021 according to the established practice in the routes mapped through biotopes suitable for nesting (Karyakin, 2004). Data on breeding territories and areas was entered in the section "Raptors of the World"59 Web-GIS "Faunistics" of the Russian Raptor Research and Conservation Network ${ }^{60}$. This section also contains data on birds of prey of I.V. Karyakin (2021), collected in 1991-1996, that was used when searching for nests. The modern structure of breeding groups of birds of prey was compared with them.

Inhabited nests of eagles were examined and nestlings were ringed in 2016, 2017, 2019, and 2021 from the end of May to the first half of June. At this time, in the central part of the Volga-Kama Territory, in most of the nests of eagles, the age of nestlings was from 30 to 60 days. In 2016, nestlings in one nest were tagged with colored rings of the Middle Volga color scheme (Karyakin et 
же распространены сосновые и широколиственные леса. Рельефр понижается к западу и югу, гле леса занимают камские террасы. В западной части территория спускается по террасам к р. Сиве, которая впадает в Каму ниже Воткинской гидроэлектростанции (Аалее ГЭС), на юге - к излучине Камы. В зависимости от типов почв и их увлажнённости здесь также произрастают леса таёжного облика с елью и пихтой, сосновые и широколиственные леса. Имеются забо^оченные участки на средних террасах. В заболоченных притеррасных понижениях в ки черноольховых лесов. В пойме р. Сивы есть небольшие островки лиственных пойменных лесов. В низовьях р. Сивы и в $а$ омине р. Камы ниже Воткинской ГЭС сохраняются участки типичной поймы с мугами и старичными озёрами, фррагментами пойменных месов. Севернее Костоватовского бора в состав НП входит узкая береговая полоса с месными экосистемами на береговых скАонах вАОАь Воткинского водохранилиша и участок леса у побережья вблизи населённого пункта Галево.

В правобережной части Камы к НП относятся лесные участки Нечкинского месничества на береговых и овражно-балочных склонах ниже устья р. Сивы $о$ окрестностей села Нечкино. Большая часть Нечкинского лесничества расположена на террасах в мевобережье р. Камы (Закамье), гле непосредственно граничит с Чайковским месничеством Пермского края. В долине Камы здесь также сохраняется пойма со старичными озёрами, заболоченными участками, пойменными месами и небольшими фррагментами лугов. В южной части лесничества в ^евобережье Камы посреди боровой террасы расположено крупное озеро Заборье. ЗАесь также сохраняются таёжные участки лесов, сосновые и широколиственные леса.

В целом наличие в НП участков лесов С высокоствольными старовозрастными $\Delta е-$ ревьями хвойных поро - сосна и миственница вАоль береговой зоны в обоих лесничествах созАаёт благоприятные условия мля гнездования такого околоводного хишника, как орлан-белохвост. Наличие черноольховых лесов на заболоченных участках притеррасной поймы создаёт условия мля гнездования большого подорлика.

\section{Используемые термины}

Гнездовой участок - охраняемая парой территориальных птиц территория вокруг гнезда (Карякин, 2004; Романов, Мастеров, 2014; Витер, 2015). al., 2018). Since 2017, nestlings have been tagged with rings, the color scheme of which is intended for the Kama basin above the borders of Tatarstan (Karyakin et al., 2018) (fig. $1)$; all information was entered into the online database "Ringing" on the RRRCN ${ }^{61}$ website.

During nests examination, the breeding success was studied, the difference in the breeding time of individual pairs was determined. To define the age of the White-Tailed Eagle nestlings, the wing length was measured (Helander, 1981), and the development of the feathers was compared (Bekmansurov, 2018). We studied prey items which were fixed according to remains found under the nests and in them. We also studied anthropogenic factors influencing on the breeding process, features of nesting stereotypes: choice of biotope, species composition of nesting trees, features of nests and their location.

\section{Results of the conducted field work and analysis of the state of the studied species \\ 1. White-Tailed Eagle (Haliaeetus albicilla) \\ 1.1. Breeding territories in Kostovatovsky Forestry}

In the first half of the 1990s, before the formation of the NP, on the right bank of the Kama River in the Kostovatovsky pine forest from the village of Kostovatovo to the mouth of the Siva River, 4 breeding territories were recorded: one above the Votkinsk HPS with a nest on a larch (Larix sibirica) and three below it with nests on pines (Pinus sylvestris). The approximate distances between them along the Kama coastline were 5.2, 3.5, and $10.6 \mathrm{~km}$ (Karyakin, 2021).

In 2017, we identified nests only within three breeding territories. One nest was above the Votkinsk hydroelectric power station and two below it. These nests were 0.9-1.6 km dislocated from the old nests that were known more than 20 years ago. Nevertheless, we attributed them to the same breeding areas with long-term breeding, since there were no nests in the former places and the birds obviously moved them over such a long time. It was not possible to find a nest within the $4^{\text {th }}$ breeding area located below the hydroelectric power station. Here the breeding territory could also have moved to a considerable distance, including outside the national park to the territory of the Votkinsky Forestry. As a whole, there was no compaction of breeding areas along the coastline (fig. 2).

\subsubsection{Nest HA-UDM27-2}

On April 22, 2017, a new nest was found above the Votkinsk HPS during a study of the Kostovatovsky pine forest for $9 \mathrm{~km}$ along the 
Гнездовая территория - территория, охватываюшая зону расположения всех гнезАовых построек (гнездовых участков), охотничьи участки, используемых парой птиц в течение ряда лет и гАе возможен контакт с территориальной птицей. Это фрактически, то же самое, что и «участок многолетнего гнездования〉 (Галушин, 1971). Гнездовая территория облахает набором экологических характеристик, в целом определяюших пригодность к гнездованию и выведению птенцов. Её размеры относительны и зависят от ряда фракторов, в том числе от плотности гнездяшихся пар. Основной критерий вылеления - одна стационарная пара соответствует одной гнезАовой территории.

В НП «Нечкинский» за более чем 20 лет в пределах одной гнездовой территории особи могми смениться неоднократно, и также могми смениться гнёзда и гнездовые участки.

\section{Материалы и методы}

Поиск гнёзА прово иАся в основном в 2017 и 2021 гг. по обшепринятой метоиике в ходе маршрутов, проложенных через гнездопригодные биотопы (Карякин, 2004). Аанные по гнездовым участкам и территориям вносились в раздел «Пернатые хишники Мира» ${ }^{59}$ Веб-ГИС «Фаунистика» Российской сети изучения и охраны пернатых хишников ${ }^{60}$. В этом же разделе Аоступны Аанные по хишным птицам И.В. Карякина (2021), собранные в 1991-1996 гг., на которые осушествлялась ориентация при поиске гнёзА, и с которыми произвоАилось сравнение современной структуры гнезАовых группировок хишных птиц. Надо отметить, что И.В. Карякиным производилось картирование гнёзд и встреч птиц на топографрическую карту масштабом 1:200000. Так как отсутствие в то время приборов геопозиционирования не позволяло точно определять местоположение, в этих Аанных может быть заложена погрешность в ^окациях точек $\Delta$ о 200 м.

Всем выявленным гнездовым участкам в веб-ГИС присваивались идентифрика-

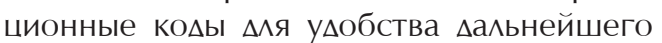
мониторинга. Пример идентифрикационного ко а: HA-UDM 26-1. В этом номере «НА» означает первые матинские буквы видового названия птицы, в Аанном случае «Haliaeetus albicilla», «UDM» означает, что гнездовая территория и гнезАо расположены в границах УАмуртской Республики, первая циорра обозначает порядковый

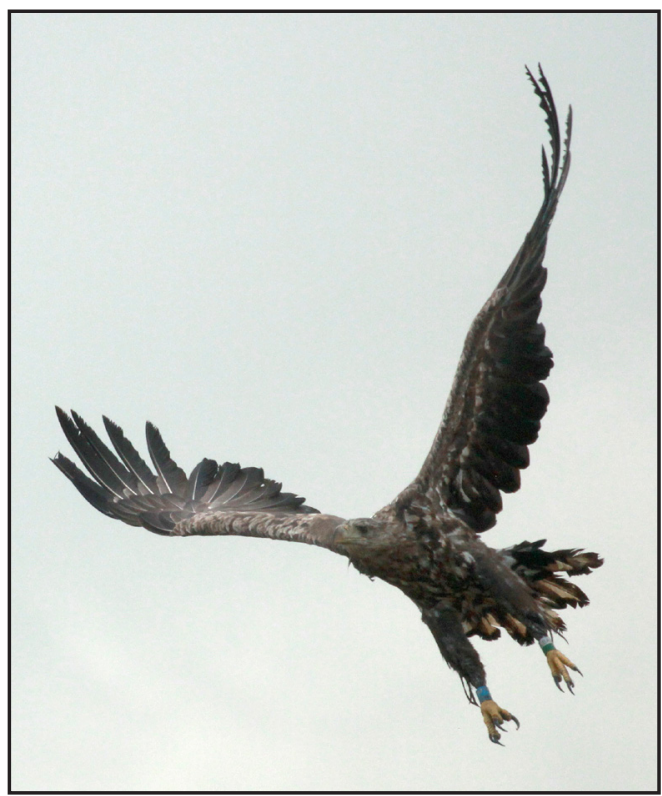

Орлан-белохвост (Haliaeetus albicilla). Фото Р. Бекмансурова.

White-Tailed Eagle (Haliaeetus albicilla). Photo by R. Bekmansurov.

coastal zone of the Votkinsk Reservoir. The nest is located on old-growth larch at the base of lateral branches of gnarled tree top at a height of $40-42 \mathrm{~m}$ and $3 \mathrm{~m}$ below the top (fig. 3). The thickness of the larch in the butt at breast height is about $1 \mathrm{~m}$, the height of the tree is over $40 \mathrm{~m}$. The breeding territory is on flat terrain in the upper part of the bedrock slope. A hiking trail is about $20 \mathrm{~m}$ from the nesting tree. It is about $60 \mathrm{~m}$ up to the edge of the coastal cliff. Examination of the nest in June showed that there was no breeding in it, no signs of the presence of birds were found. The nest was rechecked in 2019 and signs of eagles visiting it were found, but again there was no breeding recorded. During the examination of this nest on June 3, 2021, there were 2 downies with the initial feather. The dimensions of the nest were $1.2 \times 1.5 \mathrm{~m}$ in width and $0.7 \mathrm{~m}$ in height. The food remains in the nest had parts of the pike perch (Sander lucioperca) and the bream (Abramis brama). At the time of the nest examination, there were no adult birds there which was probably due to the long flight distance in search of food. For the purpose of ringing, the nest was revisited on June 16,2021 , and again there were no adult birds. The age of the older nestling in the brood (wing length $29.5 \mathrm{~cm}$ ) was about 38 days, the age of the youngest (wing length $20.5 \mathrm{~cm}$ ) - about 28 


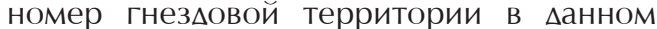
регионе, а вторая цифрра - номер гнезАа в пределах гнезАовой территории.

Проверка жилых гнёзд орланов и кольцевание птенцов проводилось в 2016, 2017, 2019 и 2021 гг. в периол с конца мая по первую половину июня. В это время на большинстве гнёзд орланов в центральной части Волжско-Камского края возраст птенцов составляет с 30 Ао 60 нней. Птенцы в 2016 г. на одном гнезде были помечены цветными кольцами средневолжской цветовой схемы (Карякин и мр., 2018). С 2017 г. птенцы метились кольцами, цветовая схема которых предназначена $м$ б бассейна Камы выше границ Татарстана (Карякин и мр., 2018). Согласно этой схеме, на правую лапу

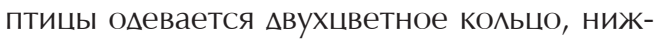
няя половина которого окрашена в зелёный цвет, верхняя - не окрашена (серебристый цвет), а на ^евую лапу птице надевается синее кольцо. Коды на обоих кольцах дублируются (рис. 1). На кольцах имеется ацрес сайта Российской сети изучения и охраны пернатых хишников (WWW.RRRCN.RU), на котором в разделе «Кольцевание» ${ }^{61}$ размешена орреймом Б $\Delta$ «Кольцевание». Птенцы метились в возрасте от 30 до 60 нней непосре $а$ ственно на гнёздах.

В ходе обследования гнёзд изучался успех размножения, определялся возраст птенцов, разница в сроках размножения от ельных пар. $\Delta$ я определения возраста птенцов орлана-белохвоста измеряли млину крыла (Helander, 1981) и сравнивали развитие перьевого покрова (Бекмансуров, 2018). Изучались объекты питания, которые ориксирова^ись по останкам, обнаруженным под гнёздами и в них. Также изучались антропогенные фракторы, влияюшие на процесс гнездования, особенности стереотипов гнездования: выбор биотопа, видовой

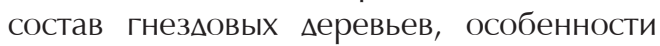
гнезАовых построек и их расположения.

\section{Результаты проведённых полевых работ и анализ состояния исследуемых видов \\ 1. Орлан-белохвост (Haliaeetus albicilla) 1.1. Гнездовые территории в Костова- товском месничестве}

В первой половине 1990-х гг., Ао образования НП, в правобережье Камы в Костоватовском бору от села Костоватово $\Delta$ о устья р. Сивы было известно 4 гнездовые территории. ОАна выше Воткинской ГЭС с гнезАом на лиственнице (Larix sibirica) и три ниже её с гнёздами на соснах (Pinus sylves- days. The difference in the age of the nestlings, according to calculations, was 10 days, although, most likely, the youngest nestling was older, and the development of its feathers was lagging behind due to insufficient feeding. At the same time, the lack of food at the time of examination of the nestlings was not recorded, the crop was filled with food in both nestlings. The nest also contained the remains of the Prussian Carp (Carassius gibelio) and other fish (Pisces sp.), feathers of a Wood Pigeon (Columba palumbus), and bird bones (Aves sp.). The latest egg laying among all examined nests in the NP in recent years was recorded in this nest. According to calculations, laying of the first egg took place here on April 2-3, and hatching approximately from May 10.

We should also note that on May 16, 1996, at a distance of about $1.6 \mathrm{~km}$ downstream of the river, also in the coastal zone of the reservoir I.V. Karyakin (2021) examined an inhabited nest on a larch. However, the nest was not preserved here, as well as other territorial eagles in the vicinity were not found. Therefore, we united both old and new breeding territories into one breeding area. However, there may be another breeding area nearby. Thus, on July 12, 2020, at a distance of 2.6 $\mathrm{km}$ from a new nest and about $1 \mathrm{~km}$ from the location of the old one (known in 1996), the NP staff found two dead fledglings that died from electrocution on power lines (PL) of 6 $\mathrm{kV}$. The origin of these young birds remains unclear. In 2021, a section of high forest with large larch trees of 30-40 m in height was additionally examined in the forest quarter 19 of the Kostovatovsky Forestry, near the place of death of two fledglings of eagles on power lines, but no nest of eagles was found there.

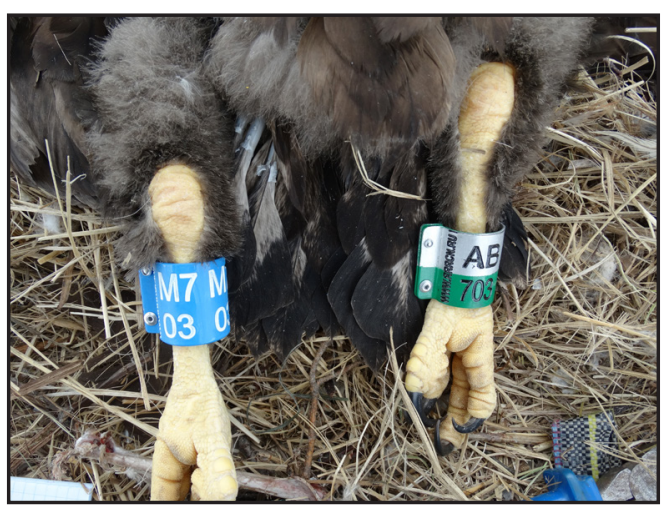

Рис. 1. Цветные кольца ция орланов-белохвостов (Haliaeetus albicilla) бассейна Камы. Фото Р. Бекмансурова.

Fig. 1. Colored rings for White-Tailed Eagles (Haliaeetus albicilla) in the Kama basin. Photo by R. Bekmansurov. 


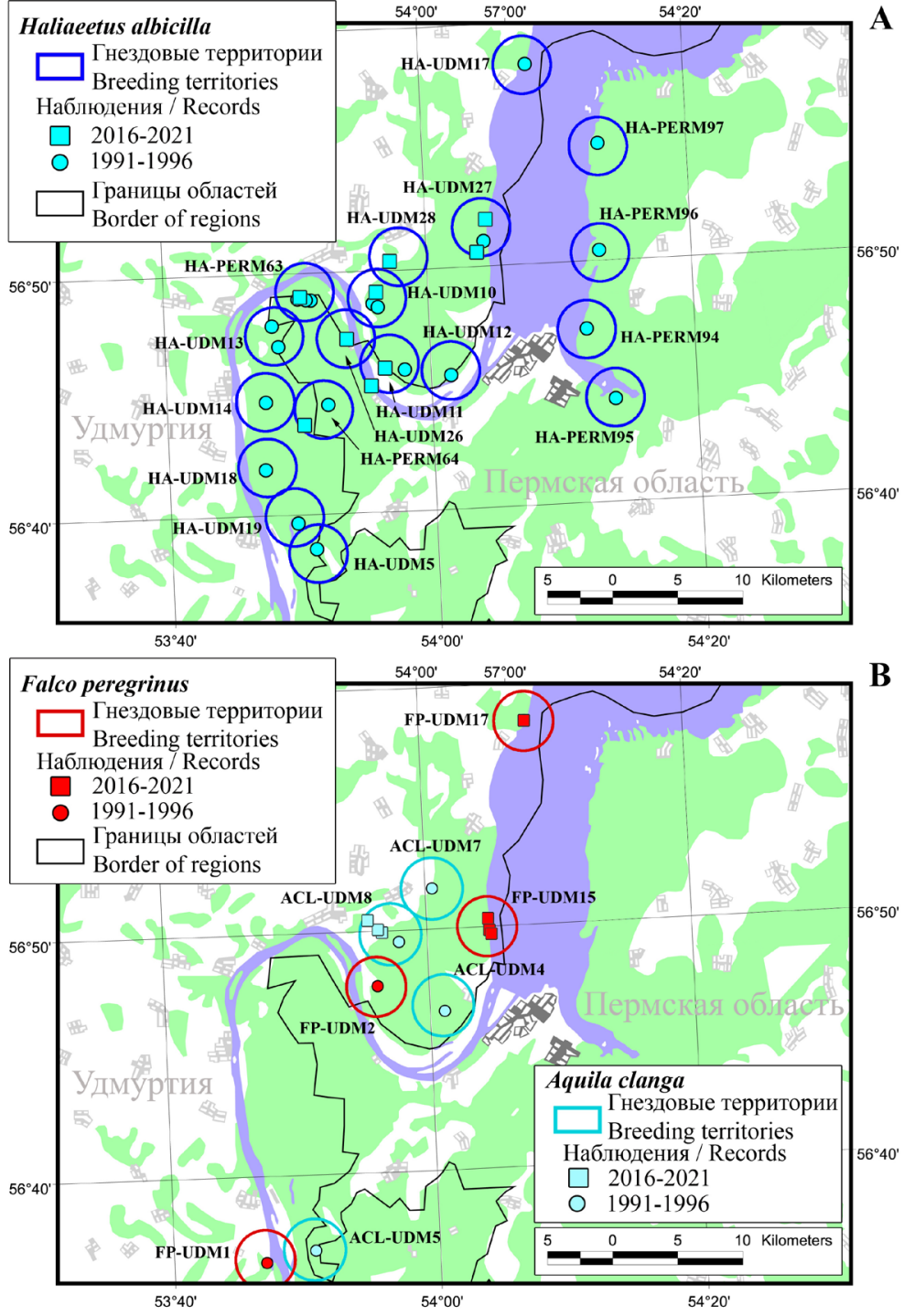

tris). Приблизительные дистанции межлу ними в оОль береговой минии Камы составмяли 5,2, 3,5 и 10,6 км (Карякин, 2021).

В 2017 г. нами выявлены гнёзда только в пределах трёх гнезАовых территорий. О$\Delta н о$ гнездо выше Воткинской ГЭС и $в$ ва ниже её. Эти гнёза расположены со смешением 0,9-1,6 км от мест расположения старых гнёзА, которые были известны более 20 лет назац. Тем не менее, мы отнесли их к одним и тем же гнездовым территориям с мительным размножением, поскольку на прежних местах гнёзда отсутствовали и явно птицы переместили их за столь продолжительное время. В пределах 4-й гнездовой территории, расположенной ниже ГЭС, обнаружить гнездо не удалось. Вероятно, зАесь гнездовой участок мог также сместиться на значительное расстояние, в том числе за пределы национального парка, на территорию Воткинского лесничества. В целом же уплотнения гнезАовых территорий вАоль береговой минии не отмечено (рис. 2).
Рис. 2. Схема размешения гнездовых территорий орлана-белохвоста, большого подорлика (Aquila clanga) и сапсана (Falco peregrinus) в НП «Нечкинский» и на окрестных территориях.

Fig. 2. Layout of the White-Tailed Eagle, Greater Spotted Eagle (Aquila clanga), and Peregrine Falcon (Falco peregrinus) breeding territories in the NP "Nechkinsky" and in the surrounding areas.

\subsubsection{Nest HA-UDM11-2}

On May 15, 2017, below the Votkinsk HPS, a longstanding inhabited nest of the WhiteTailed Eagle was found within the pine terrace of the Kama in quarter 38 on an old-growth pine tree at the edge of the bog and about $0.3 \mathrm{~km}$ from the outer edge of the forest (fig. $4)$. The nest was located at the base of lateral branches at a height of about $30 \mathrm{~m}$ and 3 $\mathrm{m}$ from the top. The width of the nest was $1.2 \times 1.6 \mathrm{~m}$, the height was $1.4 \mathrm{~m}$. The diameter of the pine trunk in the butt was $0.85 \mathrm{~m}$. Near the nest, at a distance of about 150 m, there was a self-feeding station for elks and wild boars.

On June 2, 2017, two nestlings were ringed in this nest. The nestlings were about 50 days old. Here egg laying, most likely, took place at the end of the first decade of March, and hatching - in mid-April.

The nest was also visited on May 28, 2019. There were 2 nestlings in it. The age of the older one (wing length $31 \mathrm{~cm}$ ) was 39-40 days, the age of the younger one (wing length $30 \mathrm{~cm}$ ) - 38 days. Egg laying in this nest was approximately in March 13-15, and hatching - in April 18-20. The nest had the remains of the crucian carp $(n=2)$ and the bream $(n=2)$.

This breeding territory, during its visit on June 2, 2021, was identified as occupied by birds according to the traces of eagles found. The nest was in good condition, however, there was no breeding in the nest. The remains of a gull (Laridae sp.) were found on the ground under the nest.

The nearest breeding territory with a nest on a pine tree was found at a distance of about $1.5 \mathrm{~km}$ outside the national park (Votkinsky Forestry). We did not find a nest within the old breeding territory. Therefore, we attributed the new nest to the former breeding area, considering that there was the shift of the breeding territory here.

\subsubsection{Nest HA-UDM10-3}

Below the Votkinsk hydroelectric power station near the mouth of the Siva River, an occupied longstanding nest of the White-Tailed Eagle on an old-growth pine tree was also found 
Рис. 3. Берег Воткинского водохранилиша, Костоватовское месничество, стрелкой указано местоположение гнезда орланабелохвоста на маячной Аиственнице (A); гнездо на лиственнице $(B, C)$; птенцы в этом гнезде 03.06.2021 г. (D); птенцы в гнезде на Аиственнице в Аень кольцевания 16.06.2021 г. (E, F). Фото Р. Бекмансурова.

Fig. 3. Coast of the Votkinsk Reservoir, Kostovatovsky Forestry, an arrow indicates the location of the nest on the larch $(A)$; nest on the larch $(B, C)$; nestlings in this nest on June 3, 2021 (D); nestlings in the nest on the larch on the day of ringing, June 16, 2021

$(E, F)$. Photos by

R. Bekmansurov.

\subsection{1. ГнезАо НА-UDM27-2}

Выше Воткинской ГЭС новое гнезАо обнаружено 22 апреля 2017 г. во время обследования Костоватовского бора на протяжении 9 км вАоль береговой зоны Воткинского водохранилиша. ГнезАо распо^ожено на старовозрастной миственнице в основании боковых ветвей искривлённой вершины на высоте 40-42 м и 3 м ниже вершины (рис. 3). Толшина лиственницы в комле на уровне груди около 1 м, высота мерева свыше 40 м. Гнездовой участок на ровной местности в верхней части коренного склона. На расстоянии около 20 м от гнезАового дерева проходит туристическая тропа. $\Delta$ о бровки берегового обрыва око^о 60 м. Проверка гнезда в июне показала, что размножения в нём не было, следов присутствия птиц не выявлено. Повторно гнезАо проверялось в 2019 г. и были выявлены следы посешения его орланами, in quarter 26 on May 16, 2017. The nesting tree was located on the edge of a small upper bog of a high river terrace occupied by a COniferous-deciduous forest (fig. 5). The distance from the outer edge of the forest was about $0.53 \mathrm{~km}$. Adult birds and one immature bird were found nearby. Birds visited the nest, but for some reason breeding did not take place on this nest. The remains of a nestling were found under the nest on the ground. It probably died during the last breeding season. The nest was rechecked in 2019, but there was no breeding, although it was renewed by birds. Molted feathers of eagles and prey remains in the form of a Hedgehog skin (Erinaceus concolor), feathers of a crow (Corvidae sp.) and a duck (Anas sp.) were found under the nest.

In 2021, the nest turned out to be inhabited; it was visited on June 2 . The nest was located at the base of lateral branches at a height of $20 \mathrm{~m}$ from the ground and $2 \mathrm{~m}$ be-

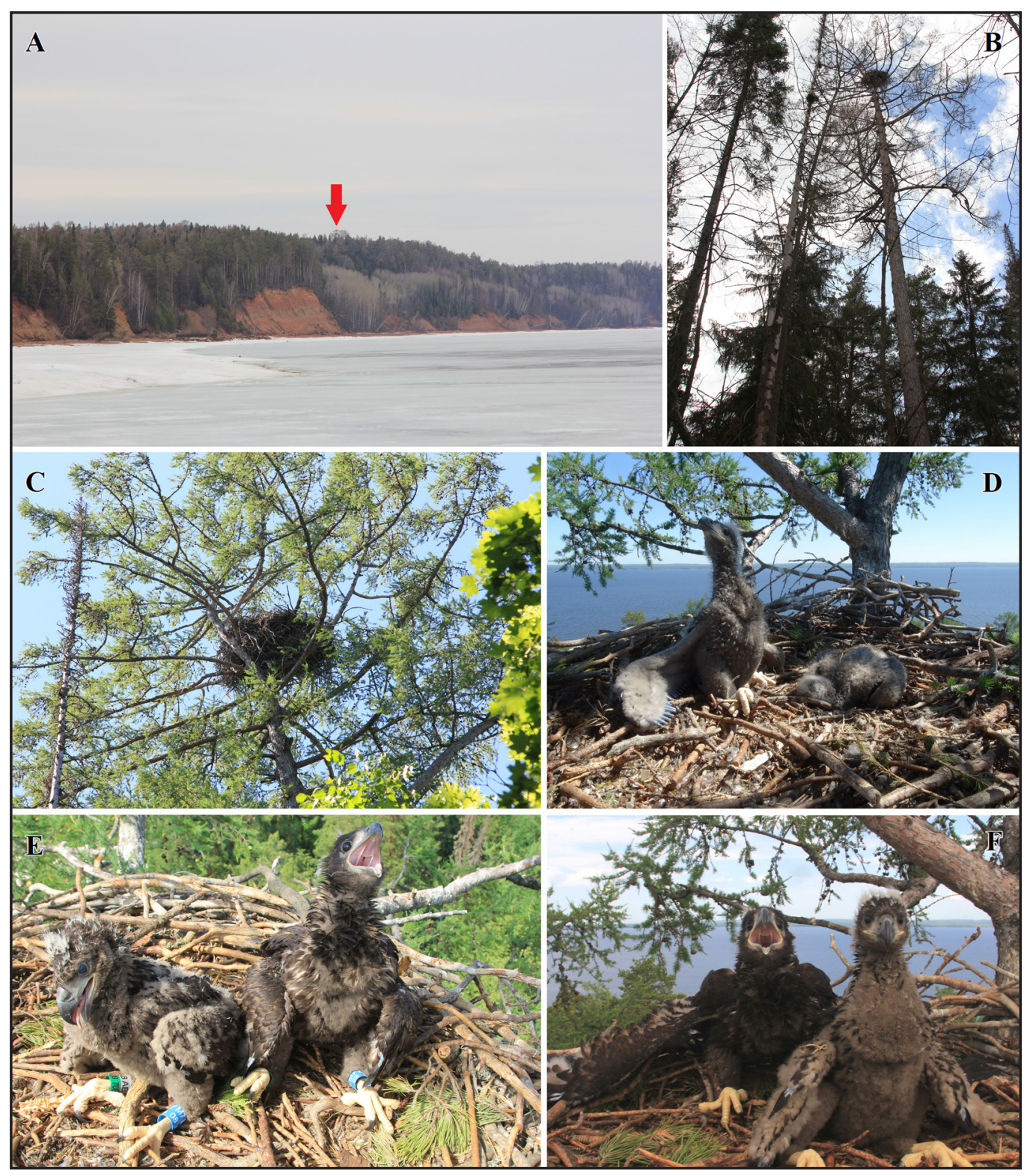


но размножение вновь отсутствовало. При осмотре этого гнезда 3 июня 2021 г. в нём находились 2 пуховых птенца на начальной стадии оперения. Размеры гнезда по ширине составили 1,2x1,5 м, в высоту - 0,7 м. В пишевых остатках в гнезде обнаружены части судака (Sander lucioperca) и леша (Abramis brama). Взрослые птицы на момент осмотра гнезда отсутствова^и, что вероятно связано с $а$ альностью полётов в поисках корма. С целью кольцевания гнезАо повторно посетили 16 июня 2021 г., и вновь взрослые птицы отсутствовали. Возраст старшего птенца в выводке (Алина крыла 29,5 см) опрелелён в районе 38 нней, возраст млацшего (мина крыла 20,5 см) - окомо 28 нней. Разница в возрасте птенцов по расчётам составила 10 нней, хотя, скорее всего, м^ахший птенец был старше, а развитие его перьевого покрова отставало вследствие недокорма. В тоже время неАостаток пиши в момент осмотра птенцов не отмечен - у обоих птенцов зобы были наполнены пишей. В гнезде также находились останки серебряного карася (Carassius gibelio) и мругих рыб (Pisces sp.), перья вяхиря (Columba palumbus) и кости птицы (Aves sp.). В этом гнезде прошла самая поздняя клахка яиц из всех проверенных гнёзА в НП за посленние годы. По расчётам отклахка первого яйца зАесь произошла 2-3 апреля, а вылупление птенцов - приблизительно с 10 мая.

Необходимо также отметить, что 16 мая 1996 г. на расстоянии около 1,6 км ниже по течению реки также в береговой зоне водохранилиша И.В. Карякиным (2021) осматривалось жилое гнездо на лиственнице. Но на этом месте гнез оо не сохранилось, как и не выявлены другие территориальные птицы орланов по соседству. Поэтому мы объединили оба гнездовых участка, старый и новый, в одну гнезАовую территорию. Тем не менее, поблизости возможно наличие ешё одной гнездовой территории. Так, 12 июля 2020 г. на расстоянии 2,6 км от нового гнезАа и около 1 км от места расположения старого (известного в 1996 г.) сотрудниками НП были обнаружены трупы Авух слётков, погибших от электротока на воздушной минии электропередачи (^ЭП) 6 кВ. Происхожление этих молодых птиц осталось невыясненным. В 2021 г. Аополнительно был обследован участок высокоствольного ^еса с крупными миственницами высотой 30-40 м в лесном квартале 19 Костоватовского лесничества, вблизи ме-

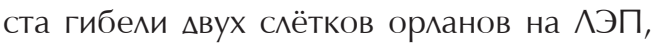
но гнездо орланов там не нашли. low the dry top. The thickness of the pine tree in the butt was $0.75 \mathrm{~m}$. The dimensions of the nest remained approximately the same as in the year when it was found (2017): 1.8x2.5 m across and $1.3 \mathrm{~m}$ in height. The surface of the nest, covered with a fresh layer, was about $1.2 \mathrm{~m}$ in diameter. There were 2 nestlings in it. The older nestling was about 32 days old (wing length $26.5 \mathrm{~cm}$ ), the younger one was about 30 days old (wing length $22 \mathrm{~cm}$ ). The nestlings were ringed. The food remains in the nest contained parts of Prussian Carp, a Blackheaded Gull (Larus ridibundus) feather, and a Muskrat (Ondatra zibethicus) skull.

This nest was assigned the number HAUDM10-3, where the number " 3 " indicated that a third nest had already been identified in this breeding territory. In the 1990s, within this territory, the breeding took place in other nests located at a distance of about $0.9 \mathrm{~km}$ (1990) and 1.1 km (1991-1996). Old nests were not found.

On August 17, 2017, in the valley of the Siva River, at a distance of $2.6 \mathrm{~km}$ from this nest, we met a pair of eagles and an immature bird, most likely a fledgling. It was suggested that in the Siva Valley, eagles could nest in the floodplain on poplars, but at a later time no nests were found here. It was not possible to establish from which of the nearest breeding territories these birds were.

\subsection{Breeding territories on the left bank} of the Kama River in the Nechkinsky Forestry and near its borders

In the 1990s, on the part of the Kama River of about $30 \mathrm{~km}$ from the mouth of the Siva to the southernmost forest areas below Lake Zaborie opposite the village of Nechkino, 7 breeding territories with nests on pines were found. At least 4 of them were located within the Udmurt Republic and, after the formation of the NP in 1997, actually ended up on its territory. The rest were on the Perm Territory. The approximate distances between them ranged from 3.8 to $5.2 \mathrm{~km}$, with an average of $4.3 \mathrm{~km}$ (Karyakin, 2021).

On June 18, 2016, on the territory adjacent to the park, we examined a previously unknown breeding territory with a nest on old-growth larch in quarter 9, Chaikovsky Forestry, Perm Territory, near the border of the quarter 80, Nechkinsky Forestry, National Park. The nest was made at the base of the lateral branches at a height of $35 \mathrm{~m}$ above ground and about 5-7 $\mathrm{m}$ from the top. The diameter of the nest was $2 \times 2.5 \mathrm{~m}$, the height was $1.5 \mathrm{~m}$. There were 3 nestlings in the nest, the oldest of them, about 70 days old, had 


\subsection{2. ГнезАо НA-UDM11-2}

Ниже Воткинской ГЭС жилое многометнее гнездо орлана-белохвоста обнаружено 15 мая 2017 г. в пределах боровой террасы Камы в квартале 38 на старовозрастной сосне с расположением гнезАового дерева на краю болота и примерно в 0,3 км от внешней опушки меса (рис. 4). ГнезАо устроено в основании боковых веток на высоте около 30 м и 3 м от вершины. Ширина гнезда 1,2х1,6 м, высота 1,4 м. Аиаметр ствола сосны в комме 0,85 м. Рядом с гнездом на расстоянии около 150 м расположена подкормочная плошахка мля лосей и кабанов.

В этом гнезде 2 июня 2017 г. бы^о проведено кольцевание $в$ ву птенцов. Возраст птенцов составлял около 50 дней. ОтклаАка яиц зАесь, скорее всего, прошла в конце первой декады марта, а вылупление - в серехине апреля. already flown. The middle and youngest nestlings were ringed. According to calculations, the laying of the first egg here could take place in early March, and the hatching of the first nestling - around April 10. Among food remains in the nest, there was the head of a Catfish (Silurus glanis), a seagull's feather, and a feather of a Gray Heron (Ardea cinerea) under the nest. The nesting tree was located at the edge of the felling site. The nest was rechecked in 2017, but there was no breeding in it. On November 5, 2021, the nest was in good condition, it was renewed by birds, and most likely there was breeding there in recent years (fig. 6). The area of the cut forest near the nest has increased.

The find of this breeding territory in 2016 initially suggested an increase in the number of breeding pairs of eagles on the left bank of the Kama River below the Votkinsk HPS. However, the assumption turned out to be
Рис. 4. Гнездовой участок орлана-белохвоста (HA-UDM 11) на краю болота с гнездом на сосне (A, B, C, D); птенцы в гнезде 02.06.2017 г. (E) и 28.05.2019 г. (F). Фото Р. Бекмансурова.

Fig. 4. Breeding territory (HA-UDM 11) at the edge of a bog with a White-Tailed Eagle nest on the pine tree $(A, B, C$, $D)$; nestlings in the nest, June 2, 2017 (E) and May 28, 2019 (F). Photos by R. Bekmansurov.

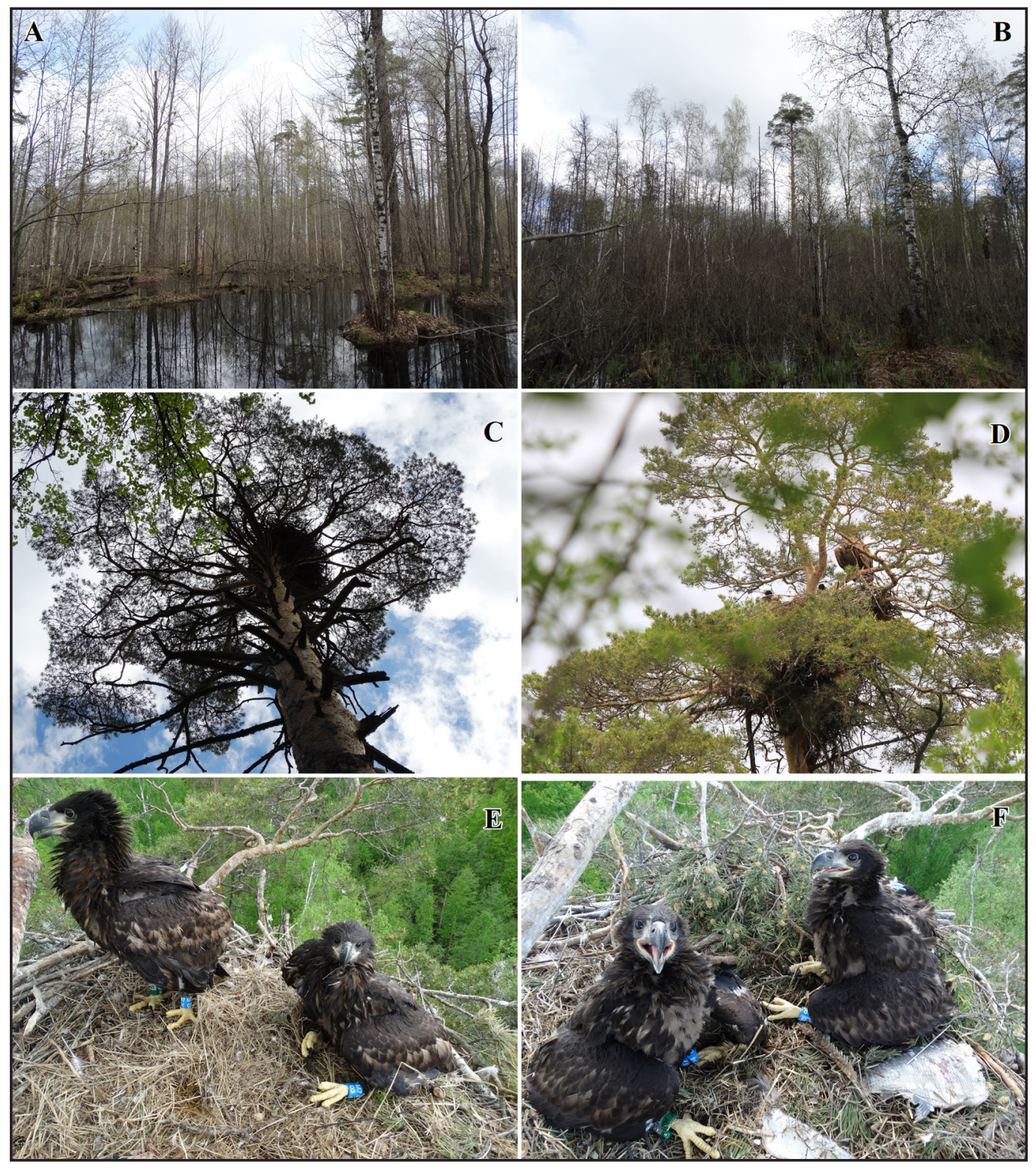


Гнездо также посешалось 28 мая 2019 г. В нём находились 2 птенца. Возраст старшего (Алина крыла 31 см) состави^ 39-40 Аней, возраст млахшего (млина крыла 30 см) - 38 нней. Откладка яиц в этом гнезде прошла приблизительно 13-15 марта, вылупление - 18-20 апреля. В гнезде обнаружены останки карасей $(n=2)$ и лешей $(n=2)$.

$\Delta$ анный гнездовой участок во время его посешения 2 июня 2021 г. определён как занятый птицами по следам присутствия орланов. ГнезАо в хорошем состоянии, тем не менее, размножение в гнезде отсутствовало. На земле под гнездом обнаружены останки чайки (Laridae sp.).

Ближайший гнездовой участок с гнез$\Delta о м$ на сосне был известен на расстоянии около 1,5 км за пределами национального парка (Воткинское лесничество). В предемах старого гнездового участка нами гнез$\Delta$ о не обнаружено. Поэтому новое гнездо мы отнесли к прежней гнезАовой территории, посчитав, что зАесь произошло смешение гнездового участка.

\subsection{3. ГнезАо HA-UDM10-3}

Также ниже Воткинской ГЭС вблизи устьевой части р. Сивы жилое многолетнее гнездо орлана-белохвоста на старовозрастной сосне обнаружено 16 мая 2017 г. в квартале 26. Гнездовое дерево расположено на краю небольшого верхового болота высокой речной террасы, занятой хвойно-широколиственным лесом (рис. 5). Расстояние от внешней опушки меса около 0,53 км. По- premature in view of the absence of other finds of nests in recent years and insufficient study of the territory of the Nechkinsky Forestry.

In 2017, attempts to find a nest within the old breeding territory HA-UDM14 opposite the village of Goliany during a partial study of quarters No. 7, 8, 9 did not result in success. Nevertheless, meetings of eagles here by the NP staff indicate a possible close location of the breeding area.

The study of quarters No. 62 and No. 69 near Zaborie Lake, where an inhabited nest was found in 1996 (breeding territory HAUDM19), did not lead to the finding of the nest in 2019 and 2021. The breeding area could probably be dislocated. Two more breeding territories remained unstudied in the Nechkinsky Forestry, where nests on pines were also recorded (HA-UDM13, HA-UDM18).

In November 2021, a section of the floodplain and adjacent terraces with a high forest on the left bank of the Kama River in quarters No. 79 and No. 80 of the Nechkinsky Forestry were examined. However, no eagles' nests were found here. On the territory of the Chaikovsky Forestry of the Perm Territory adjacent to these quarters in the quarters No. 2 and No. 3 nests on pines were recorded in the early 1990 s. In 2021, on November 5, in quarter No. 2, a perching site of eagles with abundant droppings was revealed on the ground under a large pine tree. Nesting probably continues in the adjacent territory. An additional study of the territory with the search for nests is required here.
Рис. 5. Гнездовой участок орлана-белохвоста HA-UDM10-3 С гнезАOм на сосне на краю забо^оченного участка камской террасы 16 мая 2017 г. (А, В); птенцы орлана-белохвоста в этом гнезде 02.06.2021 г. $(C, D)$.

Фото Р. Бекмансурова.

Fig. 5. Breeding area of the White-Tailed Eagle HA-UDM10-3 with the nest on the pine tree at the edge of a wetland of the Kama terrace on May 16, 2017 (A, B); WhiteTailed Eagle nestlings in this nest on June 2, 2021 (C, D). Photos by R. Bekmansurov.
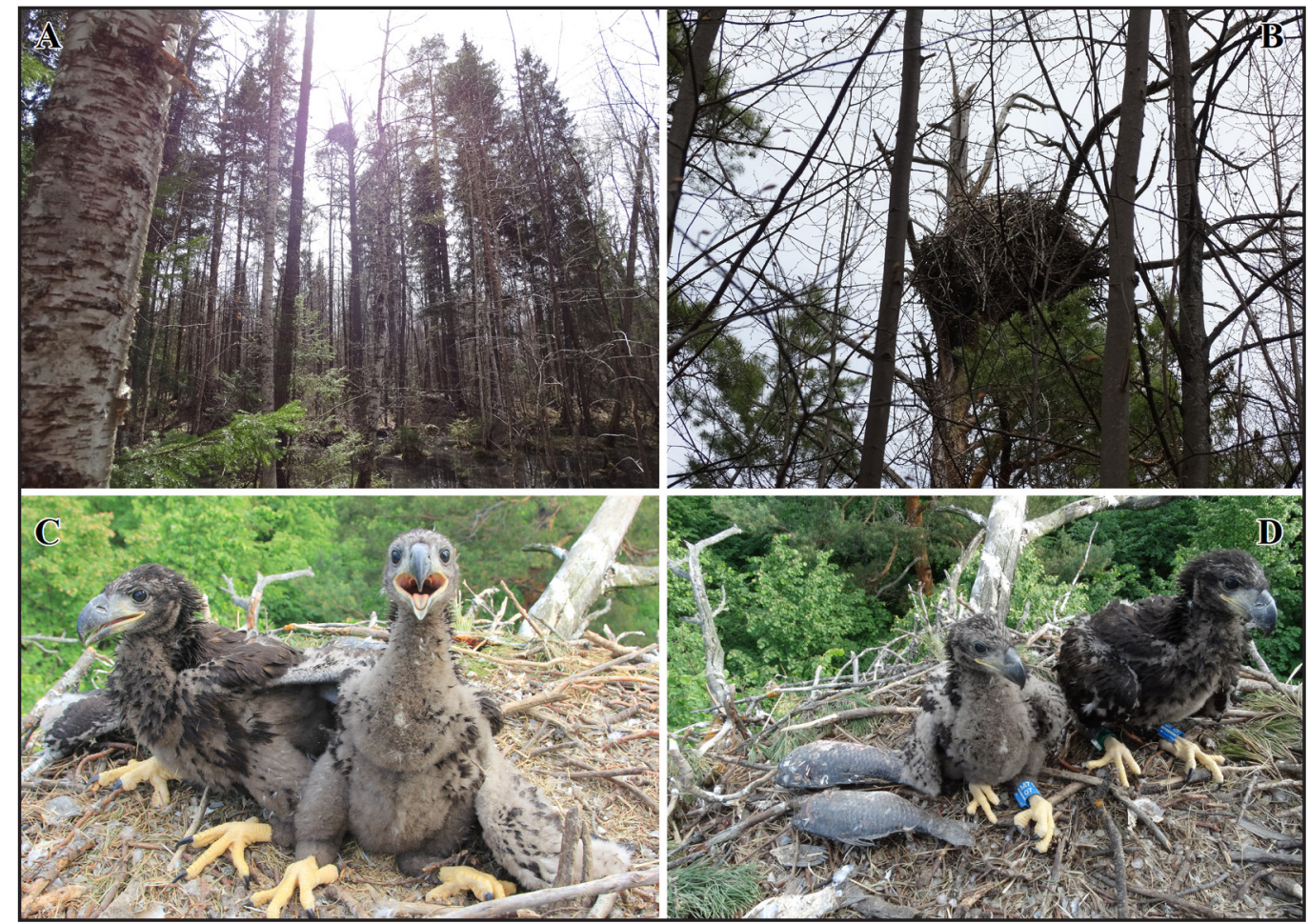
близости отмечены взрослые птицы и одна молодая. Птицы посешают гнезАо, но по

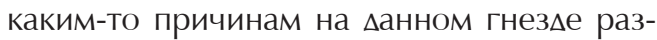
множение не состоялось. Также под гнез$\Delta$ ом на земле обнаружены останки птенца, который погиб, вероятно, в прошлый сезон размножения. Гнездо повторно проверя^ось в 2019 г., но размножение в нём также отсутствова^о, хотя оно поАновлялось птицами. Пол гнезАом найдены минные перья орланов и остатки пиши в виде шкуры ежа (Erinaceus concolor), перья врановой птицы (Corvidae sp.) и утки (Anas sp.).

В 2021 г. гнезАо оказалось жилым, оно посешалось 2 июня. Гнездо устроено в основании боковых веток на высоте 20 м от земли и ниже на 2 м от сухой вершины. Толшина сосны в комле - 0,75 м. Размеры гнезда сохраняются примерно такими же, как и в год его обнаружения (2017 г.): 1,8х2,5 м в поперечине и 1,3 м в высоту. Поверхность гнезАа, выстланная свежим слоем, около 1,2 м в циаметре. В нём находились 2 птенца. Старший птенец возрастом около 32 Аней (Амина крыла 26,5 см), млахший - возрастом около 30 мней (миина крыла 22 см). Птенцы были окольцованы. В пишевых останках в гнезме - части серебряных карасей, перо озёрной чайки (Larus ridibundus), череп ондатры (Ondatra zibethicus).

$\triangle$ анному гнезду был присвоен номер НАUDM10-3, гле циорра «3» указывает на то, что на этой гнезАовой территории уже выявлена 3-я гнездовая постройка. В 1990-е годы в пределах этой территории размножение происходило на Аругих гнёздах находяшихся на расстоянии около 0,9 км (1990-й г.) и 1,1 км (1991-1996 гг.). Старые гнёзда не обнаружены.

В молине р. Сивы на расстоянии 2,6 км от этого гнезАа 17.08.2017 г. мы встретили пару орланов и молодую птицу, скорее всего слётка. Бы^о слелано предположение, что в $А$ оине Сивы орланы могли гнездиться в пойме на тополях, но в последуюшем гнёз з зесь не обнаружили. С какой из ближайших гнезАовых территорий были эти птицы, установить не уда^ось.

1.2. Гнездовые территории на мевобережье р. Камы в Нечкинском кесничестве и вблизи его границ

В 1990-х гг. на отрезке Камы около 30 км от устьевой части Сивы $\Delta$ о самых южных ^есных кварталов ниже озера Заборье напротив села Нечкино были выявлены 7 гнездовых участков с гнёздами на соснах. По крайней мере 4 из них находились в пределах УАмуртской Республики и, после
In November of 2021, a study of a forest area on the adjacent territory on the southern outskirts of the Nechkinsky Forestry near the boundaries of quarters 74-75, where a nest on a pine tree was also recorded in 1996 (HAUDM5-1), did not lead to finding the nest. On the day of the examination, a fresh felling area was found near this territory, where clear cutting was made.

In general, the left-bank area of the national park, belonging to the Nechkinsky Forestry and the territories of the Chaikovsky Forestry bordering the park, remained insufficiently studied. However, we assume that the number of breeding areas since the beginning of the 1990s could not decrease and, at least, remains at the same level - no less than 4 breeding areas within the NP and no less than 3 - in the immediate vicinity of its borders. The dislocations of the breeding territories in the Kostovatovsky Forestry up to 1.5 and 1.6 $\mathrm{km}$ from the locations of old nests show that the same dislocations could have occurred in the breeding areas in the Nechkinsky Forestry. When looking for nests, we need to focus on covering a larger area of the forest. The abundance of forest areas with large old-growth trees along the Kama coast creates good conditions for eagles to nest.

Despite the incomplete study of the NP territory, we assume the presence of 8-9 breeding areas within it, and $2-3$ areas directly along its borders. Thus, the number of breeding pairs of eagles in comparison with the first half of the 1990s, in our opinion, remains stable, and an increase in the number, as it happened on the Lower Kama in Tatarstan, was not recorded here. Moreover, in the lower reaches of the Kama River as their numbers increased, the eagles en masse have began to nest in floodplain lighted forest sites, mainly on poplars and willows. Their nests are often clearly visible from afar, especially in the absence of foliage. Within the NP "Nechkinsky" in the floodplain forests, breeding territories have not formed. Indirectly, this is also an indicator of the absence of growth in the number of the nesting group of the eagle in the given territory. At the same time, the White-Tailed Eagle has become a rather noticeable bird in comparison with the end of the XX century which may be associated with an increase in the total population and the number of immature birds roaming the area.

Analysis of the known breeding territories of eagles in the NP shows that the nesting trees are removed deep into the forest from the outer edge at a distance of 130 to $530 \mathrm{~m}$. The distance to the Kama Riva is $0.68 \mathrm{~km}$ on 
образования НП в 1997 г., фрактически оказались на его территории. Остальные - на территории Пермского края. Приблизительные Аистанции между ними составляли от 3,8 $\Delta$ о 5,2 км, в среднем 4,3 км (Карякин, 2021).

На сопредельной с парком территории 18 июня 2016 г. нами осматривался ранее неизвестный гнезАовой участок с гнездом на старовозрастной миственнице в квартале 9 Чайковского месничества Пермского края у границы кв. 80 Нечкинского месничества НП. ГнезАо было устроено в основании боковых ветвей на высоте 35 м от земли и около 5-7 м от вершины. Аиаметр гнезда $2 \times 2,5$ м, высота 1,5 м. В гнезде нахо ились 3 птенца, старший из них возрастом око^о 70 мней, уже лета^. Средний и млахший птенцы были окольцованы. По расчётам отклаАка первого яйца зАесь могла пройти в первых числах марта, а вылупление первого птенца - около 10 апреля. Из пишевых остатков в гнезде находились голова сома (Silurus glanis), перо чайки, под гнездом перо серой цапли (Ardea cinerea). Гнездовое дерево располагалось на краю вырубки. Повторно гнезао проверялось в 2017 г., но размножения в нём не было. При посешении этого гнезАового участка 5 ноября 2021 г. гнездо было в хорошем состоянии, оно обновлялось птицами, и скорее всего на нём происходило размножение в после ${ }^{-}$ ние годы (рис. 6). Плошадь вырубленного леса вблизи гнезда увеличилась.

Находка в 2016 г. этого гнезАового участка первоначально вызвала предположение об увеличении численности гнездяшихся пар орланов на мевобережье Камы ниже Воткинской ГЭС. Но предположение оказалось прежлевременным ввиду отсутствия Аругих нахо $\Delta$ ок гнёзд за последние годы и недостаточного обследования территории Нечкинского ^есничества.

В 2017 г. попытки найти гнезАо в премелах старой гнездовой территории НАUDM14 напротив села Гольяны при частичном обследовании кварталов 7, 8, 9 не привели к успеху. Тем не менее, встречи зАесь орланов сотрудниками НП указывают на возможно близкое расположение гнезАового участка.

Пока не привело к находке гнезда обследование в 2019 и 2021 гг. кварталов 62 и 69 у озера Заборье, гле было известно жилое гнезАо в 1996 г. (гнезАовая территория HA-UDM19). Вероятно, гнезАовой участок мог сместиться. Остались необследованными ешё 2 гнездовые территории в Нечкинском лесничестве, гле также были average (from 0.13 to $1.3 \mathrm{~km}, n=4$ ). Eagles nest on large, old-growth pines and larch trees, crown architectonics of which is convenient for fixing nesting material. The thickness of nesting trees in the butt at a height of $1.3 \mathrm{~m}$ averages $0.9 \mathrm{~m}$ (from 0.75 to $1.0 \mathrm{~m}, n=4$ ). The presence of large old-growth pines and larch trees in the coastal zone, the status of specially protected natural areas could contribute to an increase in the number of breeding pairs, but the limiting factor here is clearly the limited food reserve, which prevents the densifying of the breeding areas along the coast of the Kama. The minimum distance between the nearest neighboring breeding territories $(n=3)$ below the Votkinsk HPS to the mouth of the Siva River, is currently $3.6 \mathrm{~km}$ long, with an average of $3.9 \mathrm{~km}$. This is probably the area of the Kama River which is the most abundant in food. Downstream and upstream distances may vary.

The period of egg laying extends for a month from the beginning of March to the beginning of April. The earliest egg laying took place in 2016 and, according to calculations, fell on approximately March 1-2. The latest breeding took place in 2021 with egg laying around March 25 and April 2-3 in two different nests. In general, the periods when the breeding started and their asynchrony correspond to those in the central part of the Volga-Kama Territory (Bekmansurov, 2019).

The identified breeding territories in the NP "Nechkinsky" are located in the following functional zones: 1 territory - in the zone of educational tourism, 2 - in a specially protected area.

In recent years, information has been received on the death of only immature whitetailed eagles. Thus, on December 12, 2019, two corpses of immatures in the non-freezing area of the lower pond of the Votkinsk hydroelectric power station were carried by the current of the Kama onto the ice in the area of the Sidorovy Gory settlement (S.V. Mashkin, pers. com.). The exact cause of death has not been established. The birds could have died on power lines near the hydroelectric power station.

The death of two fledglings from electrocution on a $6 \mathrm{kV}$ power line in a cleared strip in the Kostovatovsky Forestry, corpses of which were found on July 12, 2020, influenced the adoption of emergency measures to protect birds: the owners of power lines were obliged to equip the pole heads with special bird protection devices.

The study of migrations of White-Tailed Eagles using color rings, which began in 2016, has given first positive results. Thus, on June 
Рис. 6. ГнезАо орлана-белохвоста на лиственнице в Чайковском лесничестве 5.11.2021 г. (А, В); птенцы в этом гнезАе в Аень кольцевания 18.06.2016 г. (C, D). Фото Р. Бекмансурова.

Fig. 6. White-Tailed Eagle nest on the larch in Chaikovsky Forestry on November 5, 2021 $(A, B)$; nestlings in this nest on the day of ringing, June 18, 2016 (C, D). Photos by R. Bekmansurov.
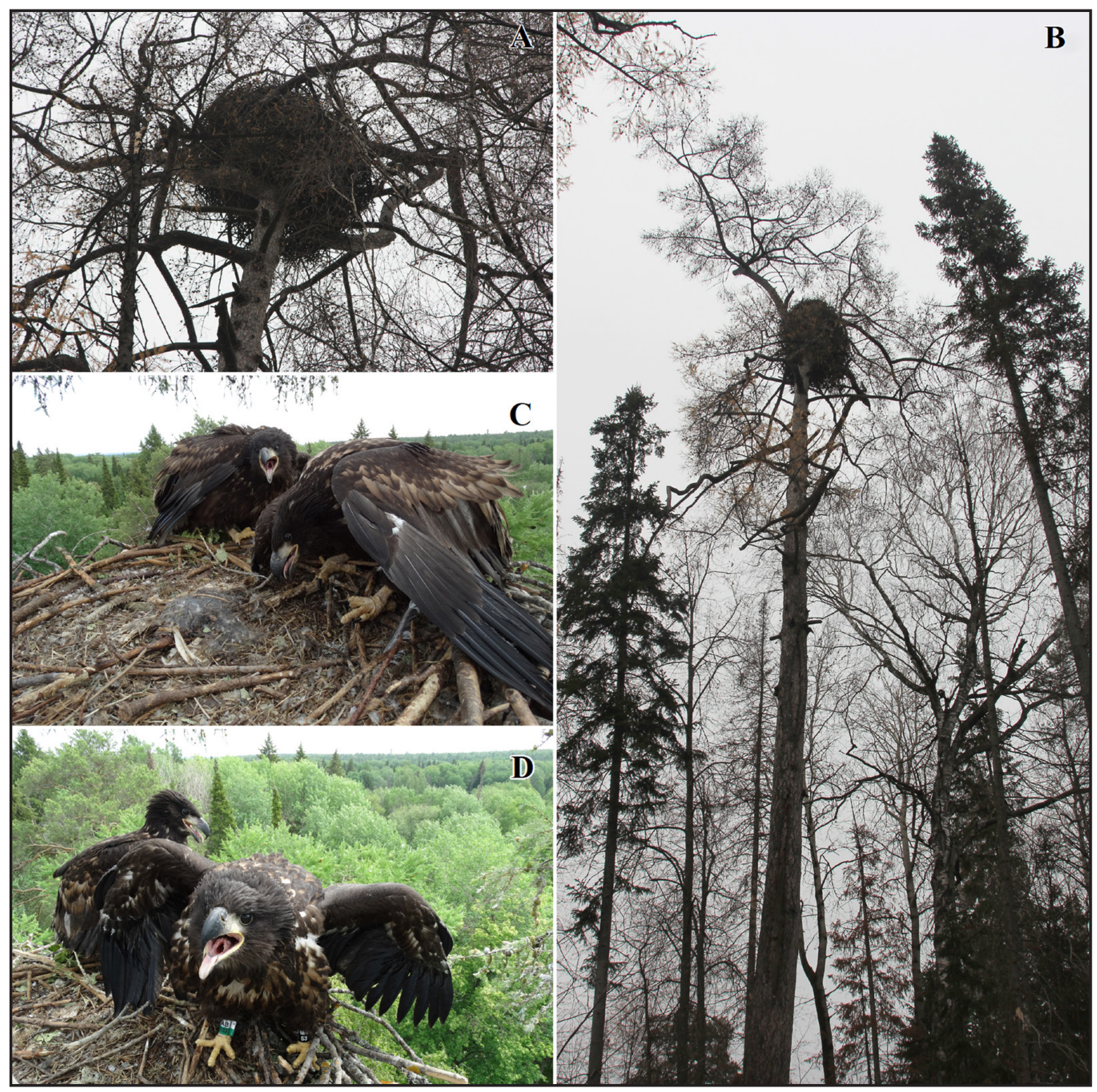

известны гнёзда на соснах (HA-UDM13, HA-UDM18).

В ноябре 2021 г. также был обследован участок поймы и прилегаюших к ним террас с высокоствольным лесом левобережья Камы в кв. 79 и 80 Нечкинского лесничества. Но гнёзд орланов не обнаружено. На сопредельной с этими кварталами территории Чайковского месничества Пермского края в кв. 2 и 3 были известны гнёзАа на соснах в начале 1990-х гг. В 2021 г. 5 ноября в кв. 2 выявлена присада орланов с обильным помётом на земле по крупной сосной. Вероятно, на сопредельной территории гнездование продолжается. 3Аесь необходимо Аополнительное обследование территории с поиском гнёзА.

Не привело к находке гнезда обследование в ноябре 2021 г. участка леса на сопредельной территории на южной окраине Нечкинского месничества у границ кварталов 74-75, гле также в 1996 г. бы^о известно гнездо на сосне (HA-UDM5-1).

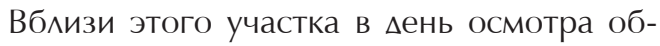
наружена свежая лесосека, гле провелена сп^ошная рубка ^еса.
6, 2020, an immature bird with colored rings on its legs was photographed in the KamskoIkskaya floodplain within the Nizhnekamsk Reservoir (Tatarstan) during the monitoring of a local breeding group of eagles. The color scheme of the rings: green area of the ring on the bottom, silver on the top on the right leg, blue with a white code on the left leg. It was not possible to read the numbers of the rings in the photographs. But until that time, only 4 nestlings were tagged with such rings - siblings from the same nest on a pine tree located in the Kostovatovsky Forestry (nest HA-UDM11-2). Two of them were tagged in 2017 and two in 2019. The immature bird photographed in the Nizhnekamsk Reservoir by external signs of its plumage corresponded to the first year of life. This means that it was one of the siblings tagged in the NP "Nechkinsky" in 2019 in a nest in the Kostovatovsky Forestry. The distance from the place of birth to the place of meeting the bird was about 106 km (fig. 7, 9).

On April 2, 2021, a photographer from Izhevsk, V.A. Lozhkin, photographed a WhiteTailed Eagle in its $5^{\text {th }}$ year of life from a hide on a pre-made bait on the Kama ice in the 
В целом левобережный участок национального парка, относяшийся к Нечкинскому лесничеству, и приграничные с парком территории Чайковского лесничества остались недостаточно обследованными. Но мы предполагаем, что численность гнездовых территорий с начала 1990-х гг. не могла снизиться и, по крайней мере, остаётся на том же уровне, - не менее 4-х гнездовых территорий в пределах НП и не менее 3-х - в непосредственной близости от его границ. Произошедшие смешения гнездовых участков в Костоватовском месничестве $\Delta$ о 1,5 и 1,6 км от мест расположения старых гнёзд показывают, что такие же смешения могли произойти на гнездовых территориях в Нечкинском лесничестве, и при поиске гнёз необходимо ориентироваться на охват большей плошами леса. Обилие участков меса с крупными старовозрастными Аеревьями вАоль побе-

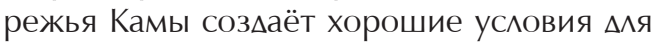
гнездования орланов.

Несмотря на неполное обследование территории НП, мы предполагаем наличие в его пределах 8-9 гнездовых территорий и 2-3 территории непосредственно в $\Delta \mathrm{O}$ ь его границ. Таким образом, численность гнездяшихся пар орланов в сравнении с первой половиной 1990-х гг., по нашему мнению, остаётся стабильной, а увеличения численности, как это произошло на Нижней Каме в Татарстане, здесь не отмечено. Кроме того, в низовьях р. Камы в ходе увеличения численности орланы в массе стали гнездиться в пойменных разрежённых участках леса, главным образом на тополях и ивах. Их гнёзда нередко хорошо видны издалека, особенно в перио отсутствия миствы. В пределах же НП «Нечкинский» в пойменных кесах гнездовые участки не сорормировались. Это тоже яв^яется косвенным показателем отсутствия роста численности гнездовой группиров-

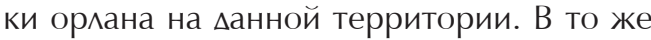
время орлан-белохвост ста^ Аостаточно заметной птицей в сравнении с концом XX века, что может быть связано с увеличением обшей численности популяции и числа неполовозрелых птиц, кочуюших по территории.

Анализ известных гнездовых участков орланов на территории НП показывает, что гнездовые деревья удалены вглубь леса от внешней опушки на расстояние от 130 $\Delta$ о 530 м. $\Delta$ истанция $\Delta$ о р. Камы в среднем состав^яет 0,68 км (от 0,13 $\Delta$ о 1,3 км, $n=4$ ). Орланы гнездятся на крупных, старовозрастных соснах и лиственницах, архитекто-
Karakulinsky region in the Ust-Belsky reserve of the Udmurt Republic. The eagle had colored rings on its legs. The numbers of the rings $\mathrm{AB}-452, \mathrm{M}-452$ were established by the photographs. These rings of the Middle Volga color scheme were on one of the three nestlings of eagles in a nest on a larch near the border of the Nechkinsky Forestry of the NP and a forestland in the Perm Territory on June 18, 2016. The distance from the place of birth to the place of meeting the bird was about $90 \mathrm{~km}$ (fig. 8, 9).

\section{Greater Spotted Eagle (Aquila clanga)}

On the territory of the NP, one habitat of the Greater Spotted Eagle is currently known. Over the past five years, solitary birds have been recorded in the floodplain of the Siva River (quarter 34) on August 17, 2017, and July 27-28, 2021 (fig. 10). At the last observation under the perching site on the bank of the Siva Riva, the remains of an eaten muskrat were found. Bird flights to the forest towards quarter 26 were recorded twice. In the direction of movement of the bird, a search for a nest was carried out and a biotope typical for nesting of this species - an alder forest in the near-terrace part of the floodplain - was fully examined, but there was no nest in this biotope. The nest could have been located on a higher terrace of the river. At the same time, it was not possible to find out the participation of this bird in breeding. In 1991, a pair of Greater Spotted Eagles was recorded within this area in quarter 26 (Karyakin, 2021).

The species-specific habitats of this species within the national park have remained insufficiently studied. It should also be noted that in the valley of the Siva River in 1991 I.V. Karyakin (2021) met another pair of Spotted Eagles. Obviously, the valley of this river within the NP "Nechkinsky" for about $14 \mathrm{~km}$ is one of the main habitats of the Greater Spotted Eagle. Floodplain meadows here ceased to be of economic importance with the end of hay-making. This was probably reflected in the deterioration of the feeding conditions of this species.

In the early 1990s on the territory adjacent to the NP, nowadays Votkinsky Forestry, I.V. Karyakin (2021) met another pair of Spotted Eagles, and on May 19, 1996, an inhabited nest was found on a pine tree on the southern border of the Nechkinsky Forestry on the left bank of the Kama River. However, these territories have not been checked by us.

\section{Peregrine Falcon (Falco peregrinus)}

Peregrine Falcons nest on the territory of the NP on the coastal cliffs of the Kama, mak- 


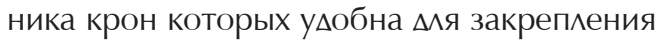
гнезАового материала. Толшина гнездовых деревьев в комле на высоте 1,3 м в среднем состав яет 0,9 м (от 0,75 $\Delta$ о 1,0 м, $n=4)$ ). Намичие крупных старовозрастных сосен и миственниц в береговой зоне, статус ООПТ могли способствовать росту численности гнездяшихся пар, но мимитируюшим фрактором зАесь явно является ограниченная кормовая база, препятствуюшая уплотнению гнезАовых территорий вАоль побережья Камы. Минимальная мистанция межАу ближайшими соседними гнездовыми участками $(n=3)$ ниже Воткинской ГЭС $\Delta \mathrm{O}$ устья р. Сивы в настояшее время составляет 3,6 км, в среднем - 3,9 км. Вероятно это наиболее кормный участок р. Камы. Ниже и выше по течению реки Аистанции могут отличаться.

Анализ Аанных мониторинга гнездования орланов в НП «Нечкинский» за послеАние годы показывает, что размножение на гнёздах происходит нерегулярно, с перерывами. Отмечено отсутствие размножения по 2-3 года, что соответствует Аанным мониторинга гнёз орланов $м$ центра^ьной части Волжско-Камского края. Причины перерывов $\Delta$ конца не изучены. Это также может быть связано с гибелью особей в территориальных парах и продолжительным периодом формирования новых пар. Сушествует также мнение, что млительные перерывы в размножении в целом свойственны орланам (Мастеров, Романов, 2014).

Период отклахки яиц растянут на месяц С начала марта по начало апреля. Наиболее ранняя отклахка состоялась в 2016 г. и по расчётам пришлась приблизительно на 1-2 марта. Наиболее позднее размножение прошло в 2021 г. с отклаАкой яиц

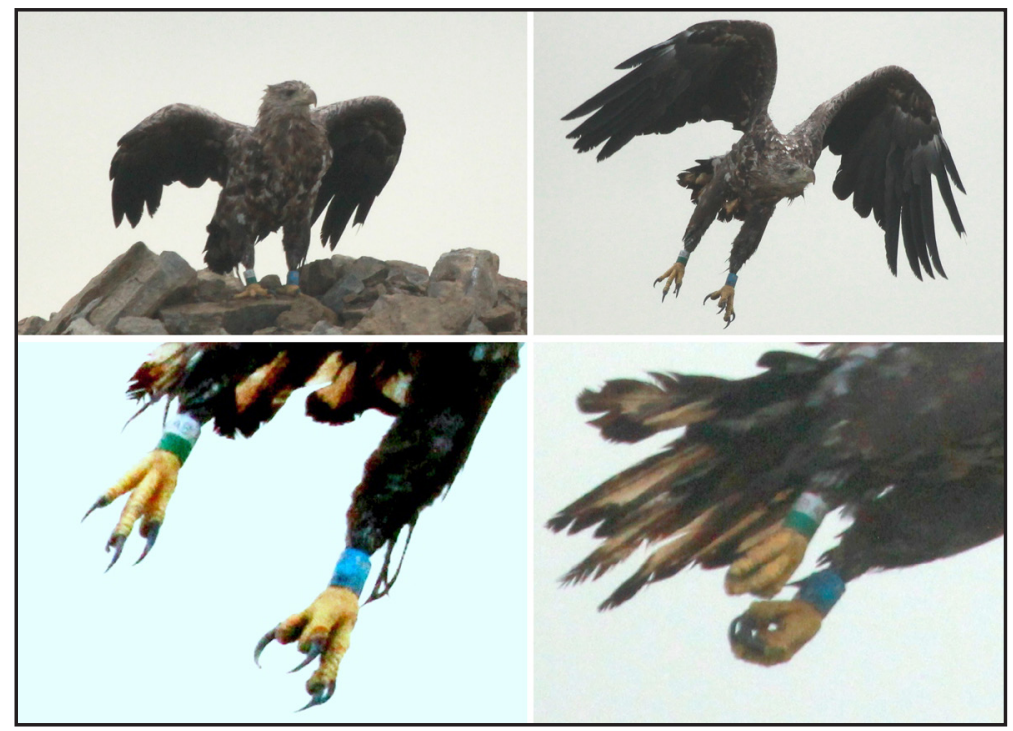

ing nests on natural cliff-shelves and in niches of Permian sediments. Over the last 5 years, breeding has been identified in two breeding territories. Thus, on April 22, 2017, a pair of Peregrine Falcons with breeding behavior was met on the coast of the Votkinsk Reservoir (breeding territory FP-UDM15). Their old nest was found. It was located on the shelf of the coastal cliff under the edge with bare tree roots at a height of about $20 \mathrm{~m}$ from the water's edge. Apparently, the birds made a new nest $200 \mathrm{~m}$ away from the old one in a subroot niche on the cliff wall (one of the birds flew out of this niche) (fig. 11).

At the beginning of June 2021, a disturbed pair of adult birds was in the former breeding territory, perching sites were found on the cliff shelves, remains in the form of feathers of Rock Dove (Columba livia) along the edge and the remains of a Greater Spotted Woodpecker (Dendrocopos major) were found, but the nest could not be found.

On the day of finding a breeding pair of Peregrine Falcons in 2017, another bird was met at a distance of about $900 \mathrm{~m}$ upstream of the Kama. In subsequent years, NP staff also met a third bird in this breeding area during the breeding season. However, the second breeding territory was not found nearby.

In 2017, the finding of a breeding pair on the coastal cliff suggested an increase in the number of peregrine falcons on the territory of the NP, since in the early 1990s only 1 territorial pair of Peregrine Falcons was recorded here and its fledglings were found below the Votkinsk HPS in the Kostovatovsky Forestry (Karyakin, 2021).

In 2021, a new breeding territory of peregrine falcons (FP-UDM17-1) was identified in the quarter 2 in the vicinity of Galevo settlement (D.A. Khodyrev, pers. com.). The nest was located near the observation deck on a sandy shelf-niche immediately under the edge of the coastal cliff. On June 16, there was one egg in the nest, most likely with a dead embryo. Adult birds stopped sitting it, but continued to defend the breeding territory (fig. 12).

Рис. 7. Молодой орлан-белохвост с кольцами на ^апах, встреченный на Нижнекамском водохранилише в Татарстане 06.06.2020 г. Фото Р. Бекмансурова.

Fig. 7. Young White-Tailed Eeagle with rings on its legs, met at the Nizhnekamsk Reservoir in Tatarstan, June 6, 2020. Photos by R. Bekmansurov. 
приблизительно 25 марта и 2-3 апреля на Авух разных гнёздах. В целом сроки начала размножения и их асинхронность соответствуют таковым в центральной части Волжско-Камского края (Бекмансуров, 2019).

Выявленные гнездовые участки в НП «Нечкинский» расположены в следуюших фрункциональных зонах: 1 участок - в зоне познавательного туризма, 2 - в особо охраняемой зоне.

За последние годы получена инорормация по гибели только молодых особей орлановбелохвостов. Так, 12 мекабря 2019 г. Ава трупа молодых птиц на незамерзаюшем участке нижнего бьеора плотины Воткинской ГЭС вынесло течением Камы на $е ̈ \Delta ~$ в районе н.п. Сидоровы Горы (С.В. Машкин, мичное сообшение). Точная причина гибели не установлена. Предположи-

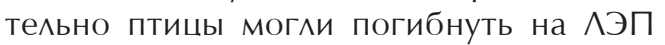
вблизи ГЭС.

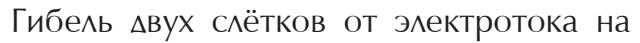
^ЭП 6 кВ на месной просеке в Костоватовском лесничестве, трупы которых были обнаружены 12 июля 2020 г., повлияла на принятие экстренных мер по зашите птиц:

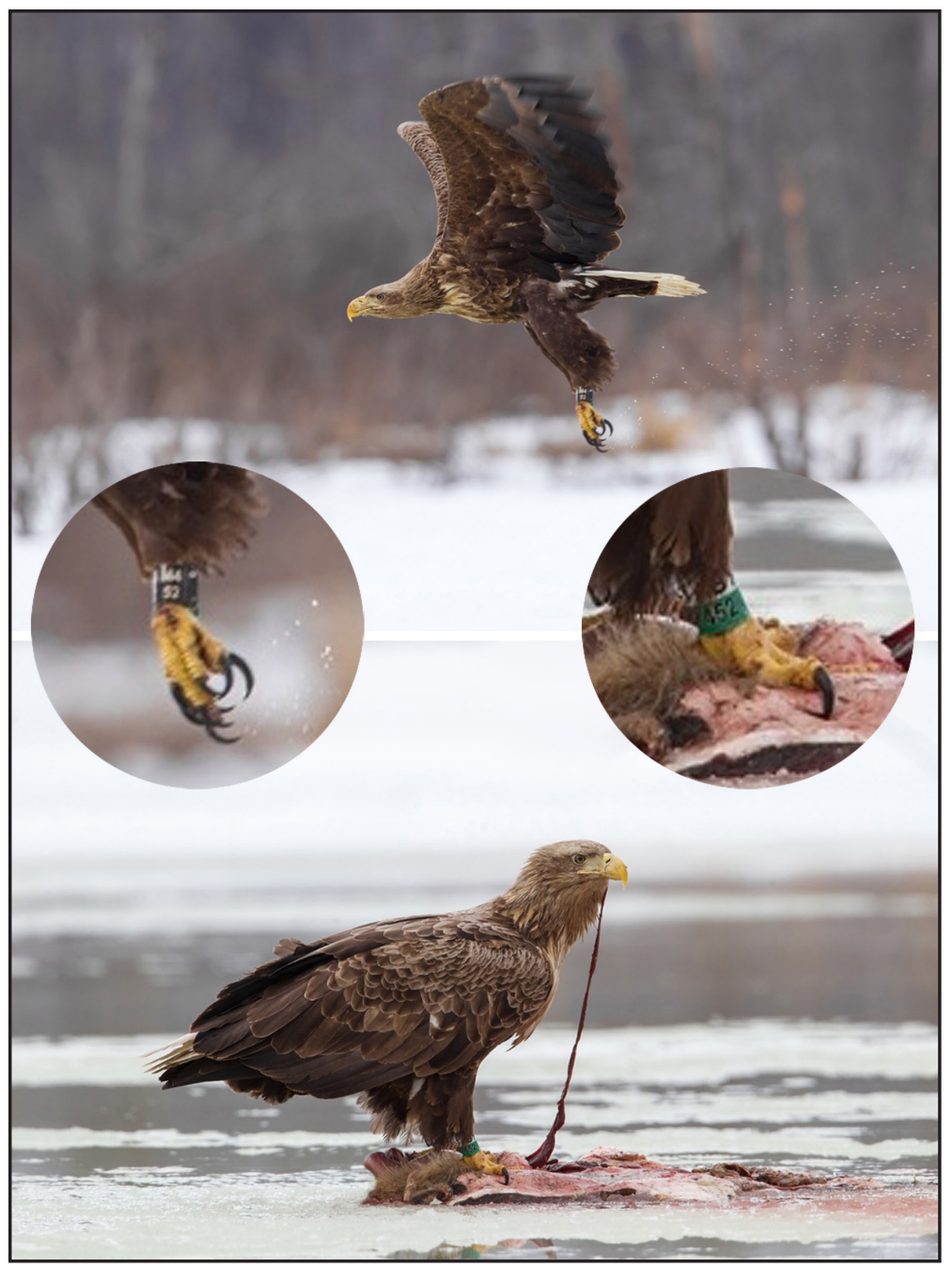

Thus, the biotopes suitable for nesting have now been examined within the coastal slope of the Votkinsk Reservoir, where 2 breeding territories have been identified with a distance of $16.5 \mathrm{~km}$ between them. The search for nests has not been completed. According to reports of bird watchers who met peregrine falcons along the right bank slope of the Kama River below the mouth of the Siva River in the territory of the Nechkinsky Forestry, there may also be breeding territories of this species.

Apparently, there was an increase in the peregrine falcon population in the NP. The population increase of this falcon on the Middle Kama led to its increase on the Lower Kama (Bekmansurov, 2020). This species requires special protection, since it often becomes the object of illegal taking from the natural environment for commercial purposes (Krever, Ivannikova, 2020).

\section{Other rare species of birds of prey}

During the recent studies, no Golden Eagles were met, and no data were obtained on the meetings of this species by anyone within the NP and near it. In 1996, 2 Golden Eagle nests were recorded in the adjacent area in the Perm Territory (Chaikovsky Forestry).

In 1996, inhabited nests of the osprey were also found in the adjacent territory in the Chaikovsky Forestry and one nest in the Kostovatovsky pine forest. However, in recent years, we have not found a nest in the same place. We also did not meet ospreys. Nevertheless, there is information about the observation of single individuals on the Kama (D.A. Khodyrev, pers. com.).

Within the studied territories along the Kama coast, the Black Kite (Milvus migrans) is quite common. Nests of this species are found on pines, lindens and oaks.

In early August of 2021 in the adjacent territory in the Chaikovsky Forestry, local residents picked up a weakened and injured nonflying nestling of the Common Honey Buzzard (Pernis apivorus) (fig. 13).

Рис. 8. Орлан-белохвост с кольцами АВ-452, М-452, соротографрированный в Каракулинском районе на р. Каме. Фото В. Аожкина.

Fig. 8. White-Tailed Eagle with rings AB-452, M-452, photographed in the Karakulinsky district on the Kama River. Photos by V. Lozhkin. 


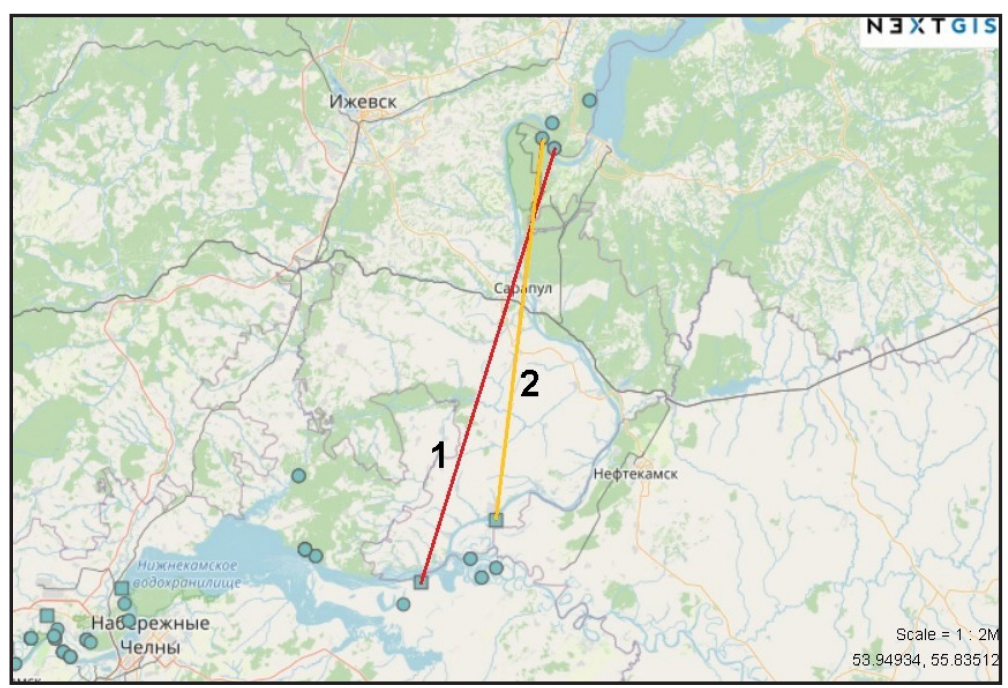

владельцев АЭП обязали оборудовать ого^овки опор специальными птицезашитными устройствами.

Изучение миграций орланов при помоши мечения цветными кольцами, которое бы^о начато в 2016 г., Аало первые положительные результаты. Так, молодая птица, имеюшая цветные кольца на лапах, 6 июня 2020 г. была соротографрирована в Камско-Икской пойме в пределах Нижнекамского водохранилиша (Татарстан) во время мониторинга местной гнезАовой группировки орланов. Цветовая схема колец: зелёное поле кольца снизу, серебристое сверху на правой мапе, синее с белым кодом на левой мапе. Номера колец по фротографриям прочитать не удалось. Но такими кольцами Оо этого времени были помечены только 4 птенца - сибсы с одного и того же гнезда на сосне, расположенном в Костоватовском месничестве (гнезАо HA-UDM11-2). Ава из них были помечены в 2017 г. и Ава - в 2019 г. Соротографрированная на Нижнекамском водохранилише молодая птица по внешним признакам оперения соответствоваяа возрасту орланов первого года жизни. А это означает, что она являлась одним из сибсов, помеченных в НП «Нечкинский» в 2019 г. в гнезде в Костоватовском лесничестве. Аистанция от места рождения $\Delta$ о места встречи птицы составила около 106 км (рис. 7, 9).

В 2021 г. 2 апреля фротографом из Ижевска В.А. Аожкиным из скрадка на установленной заранее приваце на мьду Камы в Каракулинском районе в УСтьБельском заказнике УАмуртской Республики был соротографрирован орлан-белохвост на 5-м году жизни. У орлана на лапах оказались цветные кольца. По оротографриям установлены номера колец АВ-452,
Рис. 9. Схема возвратов колец: 1 - от птицы, помеченной в гнезде HA-UDM11-2 в НП «Нечкинский» в 2019 г. (встречена 6 июня 2020 г.), 2 - от птицы с номерами колец АB-452 и М-452 (наблюдалась В. Аожкиным в Каракулинском районе). Кружки места кольцевания орланов, квадраты - места встреч окольцованных птиц.

Fig. 9. Ring recovery scheme: 1 - of the bird tagged in the nest HA-UDM11-2 in NP "Nechkinsky" in 2019 (met on June 6,2020), 2 - of the bird with the numbers of the rings $A B-452$ and M-452 (was observed by $\checkmark$. Lozhkin in the Karakulinsky district). The circles are the places of the eagles' ringing, the squares are the places of meeting the ringed birds.

In November 2021, during a study of a high forest along the eastern coast of the Lake Zaborie in the Nechkinsky Forestry, 2 nests were found, probably of Accipitridae sp. One nest on a pine, probably of a Goshawk (Accipiter gentilis), a second nest on a lateral branch of a larch were found. The species identification of these nests has to be clarified (fig. 14).

In 2021, the Ural Owl (Strix uralensis) was met twice in July and November in the same area of alder forest in the near-terrace part of the Siva River.

\section{Conclusion}

Biodiversity conservation is one of the priority tasks of protected areas. Conservation of rare species requires taking special measures which begin with address cartographic data about habitats, information about the dynamics of population characteristics, which can be obtained during monitoring studies.

In recent years, the territory of the $\mathrm{Ne}$ chkinsky National Park has become a platform for monitoring such rare species of birds of prey as the White-Tailed Eagle, the Greater Spotted Eagle, and the Peregrine Falcon within the middle reaches of the Kama River. Based on the results of studies in 2021, additional information was obtained on the state of the breeding groups of these birds of prey, which are important not only for internal use, keeping a registry, but also for understanding the state of species in Udmurtia, Perm Territory, and in the VolgaKama Territory as a whole.

There was two-three times increase in the Peregrine Falcon population in comparison with the first half of the 1990s. The nesting stereotype of this species is associated with the steep coast of the Kama River, with the location of nests on natural ledges-shelves 
М-452. Этими кольцами средневолжской цветовой схемы был помечен один из трёх птенцов орланов в гнезде на миственнице у границы Нечкинского месничества НП и месного массива на территории Пермского края 18 июня 2016 г. Аистанция от места рожления $\Delta$ о места встречи птицы составила около 90 км (рис. 8, 9).

\section{2. Большой похорлик (Aquila clanga)}

На территории НП в настояшее время известно одно место обитания большого подорлика. На протяжении последних пяти лет одиночные птицы отмечены в пойме р. Сивы (квартал 34) 17 августа 2017 г. и 27-28 июля 2021 г. (рис. 10). При послеАнем наблюдении под местом присады на берегу р. Сивы обнаружены останки съеденной ондатры. Аважыы отмечены пере^ёты птицы в лес в сторону квартала 26. В направлении перемешения птицы был осушествлён поиск гнезАа и полностью обсле-

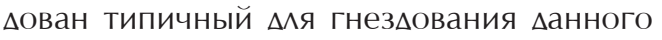
вида биотоп - ольховый лес в притеррасной части поймы, но гнезАа в этом биотопе не оказалось. Вероятно, гнезАо могло быть расположено на более высокой террасе реки. В тоже время не удалось выяснить участие этой птицы в размножении. В 1991 г. пара подорликов была отмечена в пределах $А$ анной территории в квартале 26 (Карякин, 2021).

Видоспецифичные местообитания ханного вида в пределах национального парка остались недостаточно обследованными. Необходимо также отметить, что в $о$ оине р. Сивы в 1991 г. И.В. Карякиным (2021) была встречена ешё одна пара подорликов. Очевинно, Аолина этой реки в пределах НП «Нечкинский» на протяжении около 14 км - одна из основных территорий обитания большого подорлика. Пойменные муга здесь перестали иметь хозяйственное значение с прекрашением сенокошения. Вероятно, это отразилось на ухудшении кормовых условий Аанного вида.

На сопредельной с НП территории ныне Воткинского лесничества в начале 1990-х гг. И.В. Карякиным (2021) была встречена ешё олна пара подорликов, а у южной границы Нечкинского лесничества на левобережье Камы 19 мая 1996 г. было выявлено жилое гнездо на сосне. Но эти участки нами остались не проверенными.

\section{3. Сапсан (Falco peregrinus)}

Сапсаны на территории НП гнезАятся на береговых обрывах Камы, устраивая

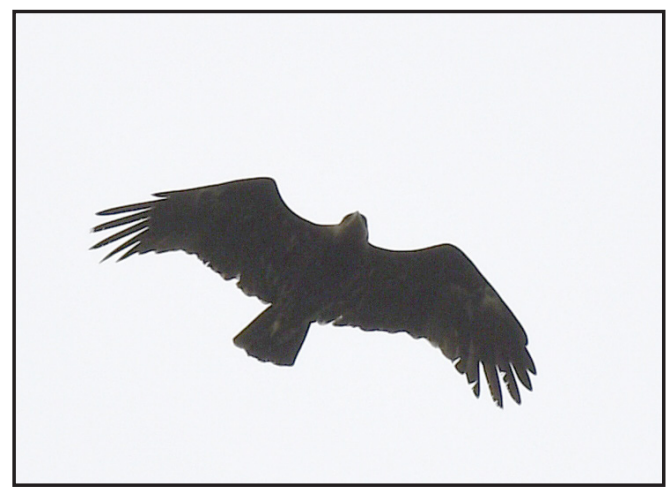

Pис. 10. Большой подорлик (Aquila clanga) в пойме р. Сивы 28 июня 2021 г. Фото Р. Бекмансурова.

Fig. 10. Greater Spotted Eagle (Aquila clanga) in the floodplain of the Siva River, June 28, 2021. Photo by R. Bekmansurov.

of coastal outcrops, nesting in trees was not found. Special control of Peregrine Falcon breeding territories is required to prevent illegal taking of nestlings from nests and catching of birds. The number of the nesting group of the White-Tailed Eagle remains stable, with at least nine breeding areas. The first information about the territorial connections of the White-Tailed Eagle was obtained from the territory of the NP, obtained by tagging the nestlings with colored rings. Information on the death of immatures in the technogenic environment is also important for understanding the scale of this problem in the region and for taking environmental measures. First of all, it is required to implement bird protection measures on 6-10 kV power lines. To protect the species in the territories bordering on the NP, measures are required to be taken to prevent felling of forests around their nests within a radius of $500 \mathrm{~m}$, which requires targeted work with forest users.

During the work, it was confirmed that the Greater Spotted Eagle continues to inhabit the valley of the Siva River. This species is hidden and the search for its nests is more difficult than the search for the nests of other eagles, therefore there is limited information about its distribution and population number. The conservation of the Greater Spotted Eagle within the Nechkinsky NP should be facilitated by a change in the use of floodplain meadows. Annual haymaking could improve feeding conditions in the hunting areas of this species, which should have an impact on the stable breeding of Greater Spotted Eagles in the study area. 
гнёзда на естественных уступах-полках и в нишах отложений пермского периода. За 5 последних мет выявлено гнездование на двух гнездовых участках. Так, 22 апреля 2017 г. встречена пара сапсанов на побережье Воткинского водохранилиша с гнездовым поведением (гнездовой участок FP-UDM15). Обнаружено их старое гнездо, которое располагалось на полке берегового обрыва пол бровкой с обнажёнными корнями Аеревьев на высоте около 20 м от уреза воды. Судя по всему, новое гнезАо птицы обустроили в 200 м от старого в подкорневой нише на стенке обрыва (из этой ниши вылетела одна из птиц) (рис. 11).

В начале июня 2021 г. на прежнем гнезАовом участке находилась беспокояшаяся пара взрослых птиц, обнаружены места присал на уступах обрыва, многочисленные поеди в виде перьев сизых голубей (Columba livia) вАОль бровки и останки большого пёстрого дятла (Dendrocopos major), но гнезАо найти не удалось.

В ень обнаружения гнездяшейся пары сапсанов в 2017 г. на Аистанции около 900 м выше по течению Камы была встречена ешё одна птица. В последуюшие годы сотрудники НП также встречали на этой гнезАовой территории третью птицу в гнезАовой сезон. Но второй гнезАовой участок поблизости не обнаружен.

Находка в 2017 г. гнездяшейся пары на береговом обрыве позволила предполо- жить рост численности сапсана на территории НП, так как в начале 1990-х годов здесь была известна только 1 территориальная пара сапсанов и встречены их слётки ниже Воткинской ГЭС в Костоватовском месничестве (Карякин, 2021).

В 2021 г. выявлен новый гнездовой участок сапсанов (FP-UDM17) в кв. 2 в окрестностях н.п. Галево ( $\triangle$.А. Ходырев, мичное сообшение). ГнезАо располага^ось поблизости от смотровой плошахки на песчаной полке-нише сразу же пол бровкой берегового обрыва. В гнезде 16 июня находи^ось оАно яйцо, скорее всего с погибшим зародышем. Взрослые птицы перестали насиживать его, но продолжали зашишать гнезАовой участок (рис. 12).

Таким образом, гнездопригодные биотопы в настояшее время осмотрены в пределах берегового склона Воткинского водохранилиша, гАе выявлены 2 гнезАовых участка с $и$ итанцией межАу ними 16,5 км. Работа по поиску гнёз не завершена. По данным сообшений наблюАателей птиц, встречавших сапсанов вАоль правого берегового склона р. Камы ниже устья р. Сивы на территории Нечкинского месничества, здесь также могут быть гнезАовые участки этого вида.

Судя по всему, в НП произошёл рост численности сапсана. Увеличение численности этого сокола на Средней Каме привело к его росту численности на Нижней Каме (Бекмансуров, 2020). Аанный вид
Рис. 11. Гнездовой участок сапсана (Falco peregrinus) FP-UDM15 22.04.2017 г. Обнажение берегового обрыва с гнезАовой полкой и сапсан на гнездовом участке. Фото Р. Бекмансурова.

Fig. 11. Breeding territory of the Peregrine Falcon (Falco peregrinus) FP-UDM15, April 22, 2017. Outcrop of the coastal cliff with a nesting shelf and the Peregrine Falcon on the nesting territory. Photos by R. Bekmansurov.

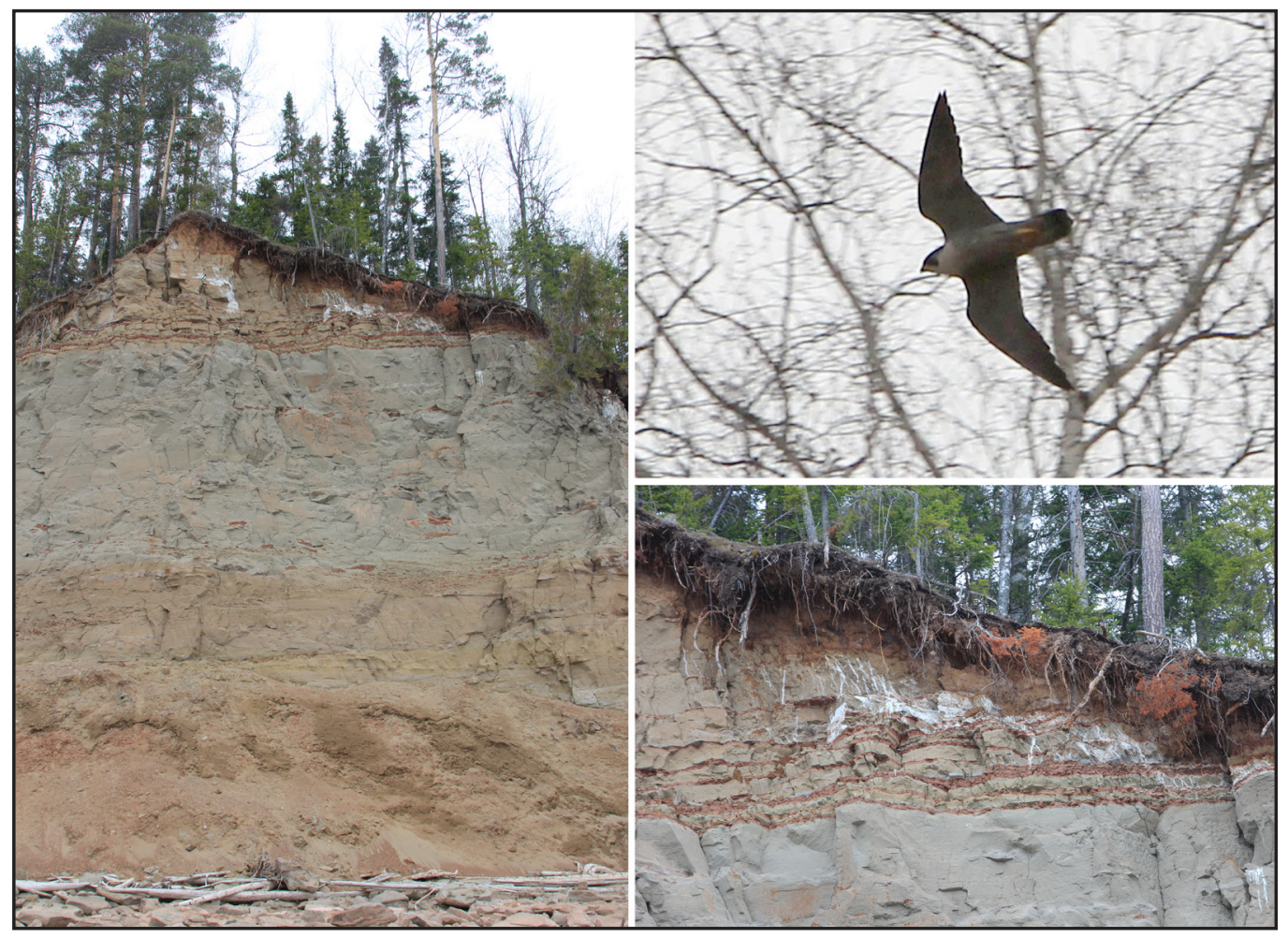




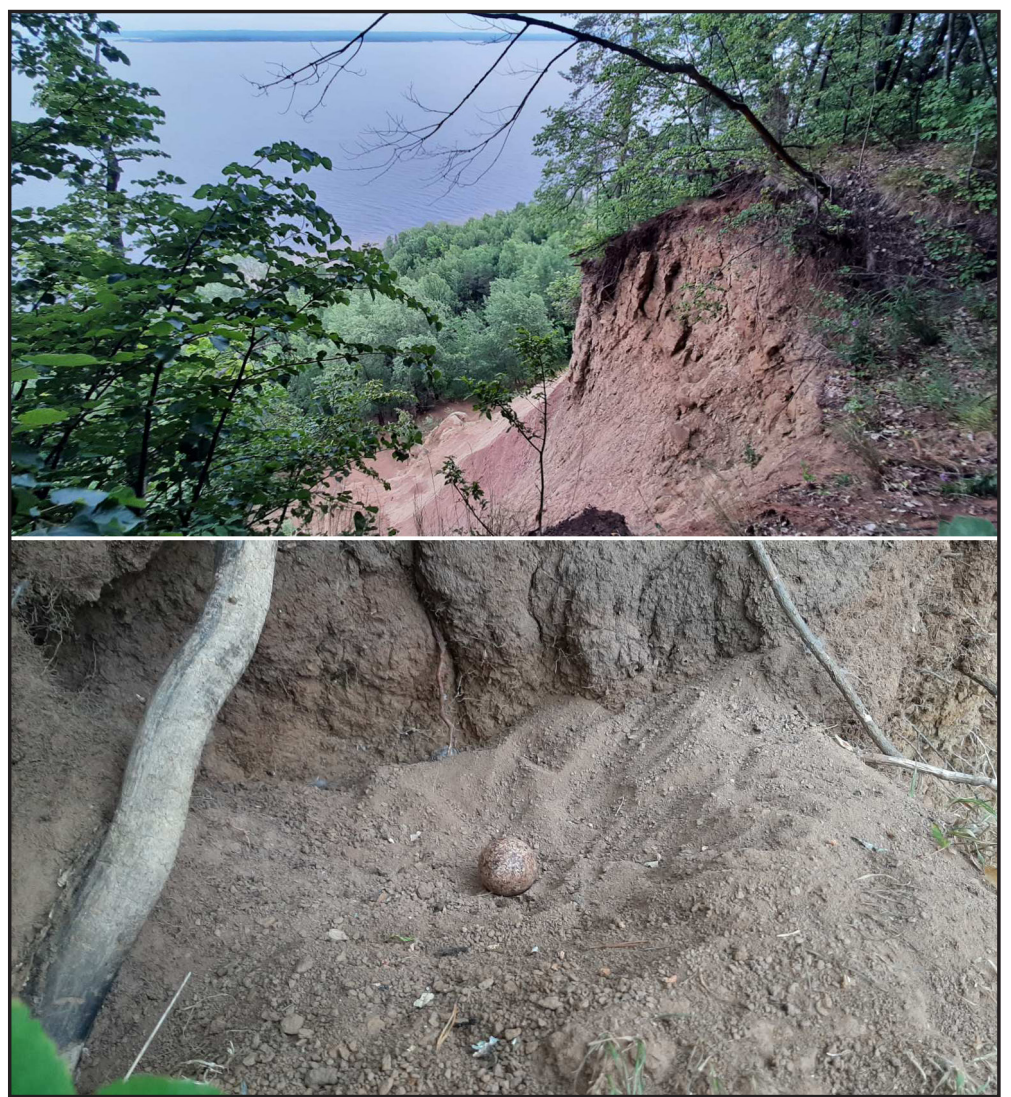

требует особой охраны, так как нередко становится объектом незаконного изьятия из природной среды с коммерческой цемью (Кревер, Иванникова, 2020).

\section{4. Аругие редкие виды хишных птиц}

За время последних исследований не было встреч беркута и не получено никаких Аанных по встречам этого вида кем-либо в пределах НП и вблизи него. В 1996 г. было известно 2 гнезда беркута на сопредельной территории в Пермском крае (Чайковское месничество).

В 1996 г. были также обнаружены жилые гнёзда скопы на сопредельной территории в Чайковском лесничестве и одно гнезАо в Костоватовском бору НП. Но в Костоватовском бору в последние годы гнезАо на прежнем месте нами не обнаружено. Скопы нами также не встречены. Тем не менее, имеются сведения о наблюдениях единичных особей на Каме (А.А. Ходырев, мичн. сообш.).

В пределах обследованных территорий вАоль побережья Камы достаточно обычен чёрный коршун (Milvus migrans). ГнёзАа этого виха обнаружены на соснах, мипах и дубе.

На сопредельной территории в Чайковском ^есничестве в начале августа 2021 г. местные жители подобрали ослабленного и травмированного ешё нелётного птенца обыкновенного осоела (Pernis apivorus) (рис. 13).
Рис. 12. ВиА на гнездовой участок сапсана FPUDM17-1 (вверху) и гнездо с одним яйцом на песчано-глинистой полке берегового обрыва (внизу). Фото А. Зыкина.

Fig. 12. View of the breeding territory of Peregrine Falcon FP-UDM17-1 (A); nest with one egg on the sand-clay shelf of the cliff (B). Photos by A. Zykin.

В ноябре 2021 г. в ходе обследования высокоствольного леса вАО ь восточного побережья озера Заборье в Нечкинском лесничестве обнаружены 2 гнезда, вероятно, приналмежашие ястребиным (Accipitridae sp.). ОАно гнездо - на сосне, вероятно, ястреба-тетеревятника (Accipiter gentilis), второе гнезАо - на боковой ветви миственницы. Видовую приналлежность гнёзд ешё предстоит уточнить (рис. 14).

В 2021 г. Аважыы в июле и ноябре на олном и том же участке ольхового леса в притеррасной части поймы р. Сивы встречена Алиннохвостая неясыть (Strix uralensis).

\section{Заключение}

Сохранение биоразнообразия - одна из приоритетных задач особо охраняемых природных территорий. Сохранение же редких видов требует особых мер, которые начинаются с аАресной картографрической инорормации о местообитаниях, сведений о динамике популяционных характеристик, которые возможно получить в процессе мониторинговых исследований.

Территория национального парка «Нечкинский» в последние годы становится плошаАкой м^я мониторинга таких редких видов хишных птиц, как орлан-белохвост, большой подорлик, сапсан в пределах среднего течения реки Камы. По резуль-

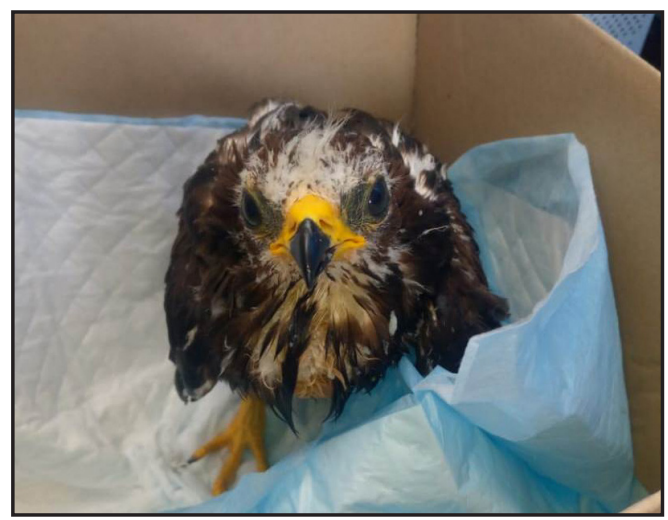

Рис. 13. Птенец обыкновенного осоеда, подобранный в Чайковском лесничестве в начале августа 2021 г. Фото А. Шаранова.

Fig. 13. Nestling of the Honey Buzzard, picked up in the Chaikovsky Forestry in early August 2021. Photo by A. Sharanov. 


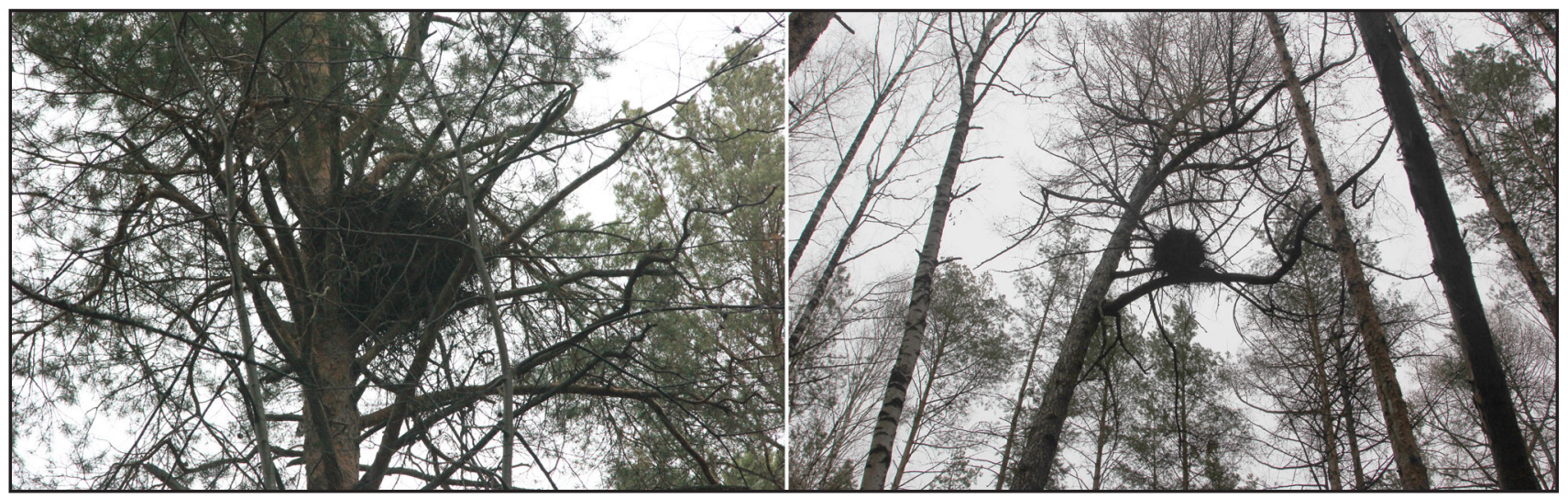

Рис. 14. Гнёзаа птиц сем. Ястребиные, не илентифицированных Ао вида, на сосне и Аиственнице. Фото Р. Бекмансурова.

Fig. 14. Nests of Accipitridae, not identified to the species, on the pine and the larch. Photos by R. Bekmansurov. татам исследований 2021 г. были получены $А$ опонительные сведения о состоянии гнезАовой группировки этих хишников,

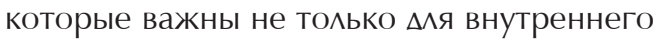

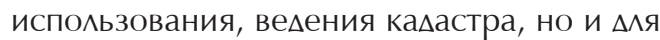
понимания состояния видов в УАмуртии, Пермском крае и в Волжско-Камском крае в целом

Произошёл рост численности сапсана в сравнении с первой половиной 1990-х гг. в $ы$ ва-три раза. Стереотип гнездования Аанного виха связан с обрывистыми берегами р. Кама, с расположением гнёзs на естественных уступах-полках береговых обнажений, гнездования на деревьях не выявлено. Необходим особый контроль гнездовых участков сапсана с целью преАотврашения незаконного изъятия птенцов из гнёз и отлова птиц. Остаётся стабильной численность гнезАовой группировки орлана-белохвоста с количеством

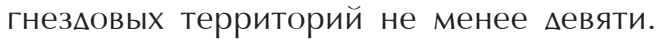
С территории НП получены первые сведения о территориальных связях орлана-белохвоста, полученные с помошью мечения птенцов цветными кольцами. Информация по гибели молодых птиц в техногенной среде также важна $А$ понимания масштабов Аанной проблемы в регионе и принятия природоохранных мер. В первую очередь требуется осушествление птицезашитных мероприя-

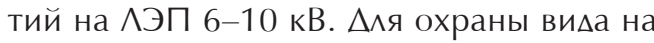
приграничных с НП территориях необходимы меры по предотврашению рубок леса вокруг их гнёз в рахиусе 500 м, $\Delta$ яя чего необхолима целевая работа с лесопользователями.

В холе работы полтвержлено, что в $\Delta$ мине р. Сива продолжает обитать большой подорлик. Этот вил является скрытным, и поиск его гнёз более труден, чем поиск

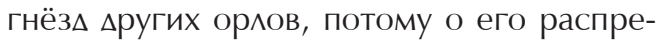
мелении и численности мало инфоорации. Сохранению большого подорлика в преде-

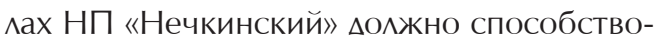
вать изменение режима использования пойменных мугов. Ежегонное сенокошение могло бы способствовать улучшению кормовых условий на охотничьих участках этого вила, что $А$ жно отразиться на устойчивом гнездовании подорлика на исследуемой территории.

\section{Благодарности}

Автор выражает благодарность ахминистрации и инспекторам национального парка «Нечкинский» за помошь в организации и проведении исследований, Р.Ф. Рахматуммину, Н.В. Бекмансуровой, А.Г. Меньшикову, $\Delta$. А. Ходыреву за помошь в отлельных этапах полевых работ, а также И.В. Карякину за формирование набора $а$ анных по гнездовым участкам хишных птиц в НП и консультации по местонахожлению гнёз на изучаемой территории в 1990-е годы.

\section{Аитература}

Бекмансуров Р.Х., Аюпов А.С. Краткий анализ результатов мониторинга орлана-белохвоста в Республике Татарстан. - Хишные птицы Северной Евразии. Проблемы и ахаптации в современных условиях: материалы VII Межлународной конореренции РГСС, г. Сочи, 19-24 сентября 2016 г. / Рех. В.П. Белик. Ростов-на- $о$ ону: изА. Южного фелерального университета, 2016. C. 220-224. [Bekmansurov R.Kh., Ayupov A.S. A brief analysis of monitoring results for the WhiteTailed Eagle in the Republic of Tatarstan. - Birds of Prey in the Northern Eurasia: Problems and adaptations in current environment: Proceedings of the VII International Conference on Birds of Prey and Owls of Northern Eurasia, Sochi, 19-24 September 2016 / V.P. Belik (Ed.). Rostov-on-Don, 2016: 220-224. (in Russian).] URL: http://rrrcn.ru/ru/archives/27385 Аата обрашения: 10.12.2021.

Бекмансуров Р.X. О возможности определения возраста птенцов орлана-белохвоста по визуальным характеристикам развития оперения. - Пернатые хишники и их охрана. 2018. № 36. C. 44-72. [Bekmansurov R.H. A possibility of de- 
termining age of nestlings of White-Tailed Eagles by means of visual features of developing plumage. - Raptors Conservation. 2018. 36: 44-72.] DOI: 10.19074/1814-8654-2018-36-4472 URL: http://rrrcn.ru/ru/archives/30504 Аата обрашения: 10.12.2021.

Бекмансуров Р.X. Аинамика сроков начала размножения орлана-белохвоста (Haliaeetus albicilla) в центральной части Волжско-Камского края и её возможные причины. - Зоологический журнал. 2019. 98(7): 825-835. [Bekmansurov R.H. The dynamics of the onset of White-Tailed Eagle (Haliaeetus albicilla) breeding in the central part of the Volga-Kama region and its possible reasons. - Zoological Journal. 2019. 98(7): 825-835. (in Russian).] DOI: 10.1134/S0044513419070031 URL: https://sciencejournals.ru/view-article/?j=zool\&y=2019 $\& v=98 \& n=7 \& a=Z o o l 1907003$ Bekmansurov $\triangle$ ата обрашения: 10.12.2021.

Бекмансуров P.X. Распространение сапсана в Татарстане на Нижней Каме и Бугульминско-Белебеевской возвышенности. - Соколы Палеарктики: Распространение, состояние популяций, экология и охрана: Материалы VIII МежАународной конореренции РГХП, посвященной памяти А.И. Шепеля, Воронежский заповедник, 21-27 сентября 2020 г. / Ред. А.Ю. Соколов, В.П. Белик. Воронеж, 2020. С. 92-97. [Bekmansurov R.H. Distribution of Peregrine Falcon in Tatarstan on the Lower Kama and the Bugulminsko-Belebeevskaya Upland. - The Falcons of the Palearctic: Distribution, populations, ecology and conservation: Proceedings of the VIII International Conference, Voronezh Nature Biosphere Reserve, 21-27 September, 2020. / A.Yu. Sokolov, V.P. Belik (Eds.). - Voronezh, 2020: 92-97.] URL: http://rrrcn.ru/wp-content/uploads/reports/ voronezh-2020/falcons-of-palearctic/Bekmansurov_2020.pdf Аата обрашения: 10.12.2021.

Витер С.Г. Наличие незанятых гнёзд и мругие фракторы, влияюшие на выбор мест гнездования хишных птиц на примере лесных местообитаний месостепной и степной зон Восточной Украины. - Пернатые хишники и их охрана. 2015. № 30. C. 72-93. [Viter S.G. Vacant Nests and Other Factors Influencing Nest Site Selection of Birds of Prey Based on Case Studies in Forest Habitats in the Forest-Steppe and Steppe Zones of Eastern Ukraine. - Raptors Conservation. 2015. 30: 72-93.] DOI: 10.19074/1814-8654-2015-30-72-93 URL: http://rrrcn. ru/ru/archives/25963 Аата обрашения: 10.12.2021.

Галушин В.М. Численность и территориальное распределение хишных птиц Европейского центра СССР. - Труды Окского государственного заповедника. Вып. 8. Москва, 1971. C. 5-132. [Galushin V.M. Number and territorial distribution of Raptors in European center of USSR. - Proceedings of the Oka State Reserve. Vol. 8. Moscow, 1971: 5-132. (in Russian).]

Карякин И.В. Пернатые хишники Уральского региона. Соколообразные (Falconiformes), Совообразные (Strigiformes). Пермь, 1998. 483 с. [Karyakin I.V. Raptors of the Ural region. Birds of prey (Falconiformes), Owls (Strigiformes). Perm, 1998: 1-483. (in Russian).] URL: http://rrrcn.ru/ru/archives/9173 $\triangle$ ата обрашения: 10.12.2021.

Карякин И.В. Пернатые хишники (методические рекоменАации по изучению соколообразных и совообразных). Нижний Новгород, 2004. 351 с. [Karyakin I.V. Raptors (methods on the study of birds of prey and owls). Nizhny Novgorod, 2004: 1-351. (in Russian)]. URL: http://rrrcn.ru/ru/archives/11151 Аата обрашения: 10.12.2021.

Карякин И.В. Скопа (Pandion haliaetus), орлан-белохвост (Haliaeetus albicilla), большой подорлик (Aquila clanga), беркут (Aquila chrysaetus), сапсан (Falco peregrinus). Пернатые хишники Мира (Веб-ГИС «Фаунистика»). 2021. [Karyakin I.V.
Osprey (Pandion haliaetus), White-Tailed Eagle (Haliaeetus albicilla), Greater Spotted Eagle (Aquila clanga), Golden Eagle (Aquila chrysaetus), Peregrine Falcon (Falco peregrinus). - Raptors of the World (Web-GIS "Faunistics"). 2021. (in Russian).] URL: http:// rrrcn.wildlifemonitoring.ru $\triangle$ ата обрашения: 10.12.2021.

Карякин И.В., Бекмансуров Р.Х., Бабушкин М.В., Важов С.В., Бахтин Р.Ф., Николенко Э.Г., Шнайлер Е.П., Пименов В.Н. Результаты работы Шентра кольцевания хишных птиц Российской сети изучения и охраны пернатых хишников в 2014 году. - Пернатые хишники и их охрана. 2015. № 30. C. 31-61. [Karyakin I.V., Bekmansurov R.H., Babushkin M.V., Vazhov S.V., Bachtin R.F., Nikolenko E.G., Shnayder E.P., Pimenov V.N. Results of work of the Raptor Ringing Center of the Russian Raptor Research and Conservation Network in 2014. Raptors Conservation. 2015. 30: 31-61.] DOI: 10.19074/18148654-2015-30-31-61 URL: http://rrrcn.ru/ru/archives/25960 $\triangle$ ата обрашения: 10.12.2021.

Карякин И.В., Николенко Э.Г., Шнайдер Е.П., Бабушкин М.В., Бекмансуров Р.Х., Китель А.А., Пименов В.Н., Пчелинцев В.Г., Хлопотова А.В., Шершнев М.Ю. Результаты работы Шентра кольцевания хишных птиц Российской сети изучения и охраны пернатых хишников в 2017 году. - Пернатые хишники и их охрана. 2018. № 37. C. 15-48. [Karyakin I.V., Nikolenko E.G., Shnayder E.P., Babushkin M.V., Bekmansurov R.H., Kitel D.A., Pimenov V.N., Pchelintsev V.G., Khlopotova A.V., Shershnev M.Yu. Results of Work of the Raptor Ringing Center of the Russian Raptor Research and Conservation Network in 2017. - Raptors Conservation.2018. 37: 15-48.] DOI: 10.19074/1814-8654-2018-37-15-48. URL: http://rrrcn. ru/ru/archives/31198 Аата обрашения: 10.12.2021.

Красная книга УАмуртской республики / Отв. ред. О.Г. Баранова. Чебоксары: «Перфректум», 2012. 458 с. [The Red Data Book of the Udmurtian Republic/ O.G. Baranova (Ed.). Cheboksary, 2012: 1-458. (in Russian).] URL: http://oopt.aari. ru/ref/663 Аата обрашения: 10.12.2021.

Кревер В.Г., Иванникова Т.О. (РеА.). Коммерческий оборот Аиких животных в Российской Федерации. Москва:

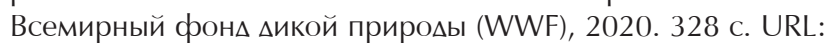
http://rrrcn.ru/ru/archives/33417 [Krever V.G., Ivannikova T.O. (Eds.) Wildlife Trade in the Russian Federation. Moscow: WWF, 2020: 1-286.] URL: http://rrrcn.ru/en/archives/33417 Аата обрашения: 10.12.2021.

Мастеров В.Б., Романов М.С. Тихоокеанский орлан Haliaeetus pelagicus: экология, эволюция, охрана. М.: ТоварищеСтво научных изданий КMК, 2014. 384 с. [Masterov V.B., Romanov M.S. The Steller's Sea Eagle Haliaeetus pelagicus: ecology, evolution, conservation. Moscow: KMK Scientific Press Ltd., 2014: 1-384 (in Russian with English summary).] URL: https:// www.researchgate.net/publication/268211102 Аата обрашения: 10.12.2021.

Приказ № 162 от 24.03.2020 Министерства природных ресурсов и экологии Российской Фелерации «Об утвержьении Перечня объектов животного мира, занесённых в Красную книгу Российской Федерации». [Order No. 162 of March 24, 2020 of the Ministry of Natural Resources and Environment of the Russian Federation "On approval of the List of wildlife objects included in the Red Book of the Russian Federation". (in Russian).] URL: http://publication.pravo.gov.ru/Document/ View/0001202004020020 Аата обрашения: 10.12.2021.

Helander B. Nestling measurements and weights from two White-Tailed Eagle populations in Sweden. - Bird Study. 1981. 28: 235-141. DOI: 10.1080/00063658109476728 URL: https:// www.tandfonline.com/doi/abs/10.1080/00063658109476728 Аата обрашения: 10.12.2021. 